Review

\title{
Natural Products as a Source for Treating Neglected Parasitic Diseases
}

\author{
Dieudonné Ndjonka ${ }^{1, \dagger}$, Ludmila Nakamura Rapado ${ }^{2, \dagger}$, Ariel M. Silber ${ }^{2}$, Eva Liebau ${ }^{3, *}$ and \\ Carsten Wrenger ${ }^{2, *}$
}

1 Department of Biological Sciences, Faculty of Science, University of Ngaoundere, B. P. 454, Cameroon; E-Mail: dede_ndjonka@yahoo.com

2 Unit for Drug Discovery, Department of Parasitology, Institute of Biomedical Science, University of São Paulo, Av. Prof. Lineu Prestes 1374, 05508-000 São Paulo-SP, Brazil; E-Mails: ludmilanr@usp.br (L.N.R.); asilber@usp.br (A.M.S.)

3 Institute for Zoophysiology, Schlossplatz 8, D-48143 Münster, Germany

$\dagger$ These authors contributed equally to this work.

* Authors to whom correspondence should be addressed; E-Mails: liebaue@uni-muenster.de (E.L.); cwrenger@icb.usp.br (C.W.); Tel.: +49-251-83-21710 (E.L.); +55-11-3091-7335 (C.W.); Fax: +49-251-83-21766 (E.L.); +55-11-3091-7417 (C.W.).

Received: 21 December 2012; in revised form: 12 January 2013 / Accepted: 16 January 2013 / Published: 6 February 2013

\begin{abstract}
Infectious diseases caused by parasites are a major threat for the entire mankind, especially in the tropics. More than 1 billion people world-wide are directly exposed to tropical parasites such as the causative agents of trypanosomiasis, leishmaniasis, schistosomiasis, lymphatic filariasis and onchocerciasis, which represent a major health problem, particularly in impecunious areas. Unlike most antibiotics, there is no "general" antiparasitic drug available. Here, the selection of antiparasitic drugs varies between different organisms. Some of the currently available drugs are chemically de novo synthesized, however, the majority of drugs are derived from natural sources such as plants which have subsequently been chemically modified to warrant higher potency against these human pathogens. In this review article we will provide an overview of the current status of plant derived pharmaceuticals and their chemical modifications to target parasite-specific peculiarities in order to interfere with their proliferation in the human host.
\end{abstract}


Keywords: neglected infectious diseases; natural compounds; schistosomiasis; river blindness; trypanosomatids

\section{Introduction}

Infectious diseases have a significant impact in human heath stock. A variety of these diseases are caused by parasites that belong to the diseases of poverty or the so-called neglected tropical diseases. Amongst others, these include the causative agents of trypanosomiasis, leishmaniasis, schistosomiasis, lymphatic filariasis and onchocerciasis. These parasites are responsible for a high rate of mortality and morbidity each year in the respective endemic countries. Since vaccines and safe and affordable treatments are still lacking, there is an urgent need to discover novel therapeutics against these human health threats. The current situation is aggravated by the fact that most people living in the endemic countries have a low-income profile, making the pharmaceutical market for the development of new medications financially unattractive to the private-research sector. Therefore, natural sources, such as plants, represent a major opportunity to discover new lead molecules [1-4]. In this review we will shed light on the discovery and application of natural plant derived products on human neglected diseases.

\section{Nematodes}

Nematodes are roundworms that belong to the phylum Nematoda or Nemathelminthes [5]. Even though the total number of nematode species has been estimated to be over 1 million [6], only about 28,000 species have been described [7], with over 16,000 of these species being parasites of plants and animals (including humans). Parasitic nematodes constitute an enormous medical and veterinary burden in some parts of the world; in the tropics, however, they represent a severe public health problem. The most common and persistent parasitic nematodes of humans are the soil-transmitted nematodes - roundworms (Ascaris lumbricoides), whipworms (Trichuris trichiura), hookworms (Necator americanus and Ancylostoma duodenale) and thread worms (Strongyloides stercoralis)—and the filarial nematodes that are responsible for lymphatic filariasis (LF) (Brugia sp, Wuchereria bancrofti) and onchocerciasis (Onchocerca volvulus).

Onchocerciasis or subcutaneous filariasis is a parasitic disease caused by $O$. volvulus. The disease affects several millions of people in the world and is transmitted from host to host by the blood-feeding "blackfly" Simulium. While more than $90 \%$ of all onchocerciasis cases are found in 30 African countries, the rest occur in isolated foci that exist in Yemen and six countries in central and South America World Health Organization [8]. About 37 million persons are infected with O. volvulus, of whom 270,000 are blind and 500,000 visually impaired [9].

LF is a mosquito-borne infection caused by the lymphatic dwelling parasites $W$. bancrofti, B. malayi and B. timori. These parasites invade and block the lymphatic system of the infected person [10]. Lymphatic vessel dysfunction and damage ultimately lead to clinical symptoms such as lymphoedema, elephantiasis and genital pathology. The WHO estimates that 1.1 billion people live in high risk areas, with 120 million people already infected with LF [11,12]. The filarial nematode 
$W$. bancrofti accounts for $91 \%$ of LF infections, while B. malayi and B. timori are responsible for the remaining $9 \%$ in the Southeast Asia region.

The burden of onchocerciasis and LF causes long term disability, social stigmatization and, in the case of onchocerciasis, forces the affected population to abandon the infested areas which usually have a high agricultural potential $[13,14]$. Thus, a high burden of onchocerciasis primarily leads to a highly unproductive population and consequently to economic loss and slowdown of country development over the years.

During the last three decades, a lot of progress has been made in the control of onchocerciasis and LF; however, the diseases still constitute a serious public health concern in the endemic countries. From 1987 to date, the control of LF and onchocerciasis has been based on two approaches: vector control using insecticides and mass drug administration of diethylcarbamazine (DEC), ivermectin and albendazole. While ivermectin is the sole drug used in community-directed treatment of onchocerciasis, DEC or ivermectin in combinantion with albendazole is used for the global control of LF [15]. The recommended treatment of filariasis patients is the administration of albendazole combined with ivermectin [16,17]. A combination of DEC and albendazole is also effective [16]. All of these treatments are microfilaricides and only show a limited macrofilaricidal activity.

The development of anthelminthic resistance is a worldwide reality [9,18-20] and also one of the greatest challenges in worm control. Early in the last decade, resistances to insecticides and ivermectin have been reported [9,18]. Additionally, a re-infestation phenomenon was observed in insecticide-treated areas. Due to these limitations, vector control was stopped. Drugs to treat onchocerciasis and LF are commonly used in combination to reduce microfilariae in the blood and skin. However, all of them have their limits. In fact, DEC or ivermectin treatment of infected individuals can cause high adverse effects [21].

Anthelmintic resistance, secondary effects and limited macrofilaricidal activities of the known antifilarial drugs have stimulated the search for alternative treatment. Here, as an alternative source of filaricidal compounds, medicinal plants have received more attention [22]. Medicinal plants have been used as therapies in traditional health care systems since prehistoric times and are still the most important health care source for the majority of the world population [23]. It is estimated that more than $60 \%$ of the world's population rely on traditional herbal medicine to meet their primary health care needs [24].

\subsection{Medicinal Plants in the Treatment and Control of Filariasis}

\subsubsection{Subcutaneous Filariasis}

Subcutaneous filariasis or onchocerciasis is a parasitic disease that is caused by $O$. volvulus. The cattle parasite $O$. ochengi is the closest known relative of $O$. volvulus with which it shares the same arthropod vector, Simulium damnosum. The O. ochengi system fills the critical niche between laboratory studies in rodent models and field evaluation of onchocerciasis control in human populations. The cattle-O. ochengi model equals that of human onchocerciasis, with nodules that closely resemble those formed by $O$. volvulus [25]. Thus it is feasible that medicinal plants, traditionally used by farmers against the bovine parasite, also affect the human parasite $O$. volvulus. 
Nyasse et al. [26] demontrated that polycarpol from Polyalthia suaveolens (Annonaceae) and 3-O-acetyl aleuritolic acid from Discoglypremna caloneura (Euphorbiaceae) exhibited significant inhibitory activities on the vitality of adult male worms of Onchocerca gutturosa.

Further studies were conducted by Cho-Ngwa et al. [27] on O. ochengi. These authors reported microfilaricidal activity of the hexane extract of Homalium africanum (Salicaceae) leaves, the hexane extract of Margaritaria discoidea (Euphorbiaciaea) roots, the methylene chloride extract of $H$. africanum leaves and the methylene chloride extract of $M$. discoidea leaves. However, none of the plants used showed macrofilaricidal activity. These Salicaceae and Euphorbiaceae are commonly used in the traditional treatment of onchocerciasis in North West Cameroon.

Using the cattle parasite $O$. ochengi, Ndjonka et al. [28] reported that ethanolic extracts of the bark of Anogeissus leiocarpus (Combretaceae) and Khaya senegalensis (Meliaceae) as well as leaves of K. senegalensis and Euphorbia hirta (Euphorbiaciaea) display high macro- and microfilaricidal activities, while aqueous extracts of leaves from Parquetina nigrescens (Asclepiadaceae) and Annona senegalensis (Annonaceae) displayed a more moderate effect on the worms viability. This was also observed using Caenorhabditis elegans, a highly suitable and free-living model organism for research on nematode parasites. Furthermore, some selected plants showed toxicity not only against wildtype C. elegans but also against drug resistant (ivermectin, levamisole and albendazole) strains [29]. Here, the most promising plant was $A$. leiocarpus (Combretaceae) with a high toxicity against $O$. ochengi, $C$. elegans wildtype and C. elegans drug resistant strains [29]. The phytochemical analysis of an A. leiocarpus extract showed a high amount of tannins, which have been reported to have a certain anthelmintic activity [30,31]. Tannins present in their composition several phenolic groups such as ellagic, gallic and gentisic acids. Gallic and gentisic acids have been reported to be toxic for C. elegans [30]. Recently, we showed that ellagic acid exhibited higher toxicity against C. elegans wildtype and drug resistant strains (Ndjonka and Liebau, personal communication). High microfilaricidal and macrofilaricidal activities were also reported with ellagic acid [29].

Thomsen et al. [32] used the anthelmintic active extracts of Hagenia abyssinica (Rosaceae) to develop a simple and inexpensive bioassay against the non-parasitic nematode C. elegans.

Katiki et al. [33] demonstrated that extracts rich in hydrolysable tannins such as Acer rubrum (Aceraceae), Rosa multiflora (Rosaceae) and Quercus alba (Fagaceae), or extracts rich in both hydrolysable and condensed tannins such as Rhus typhina (Anacardiaceae), were significantly more lethal to adult of $C$. elegans than extracts containing only condensed tannins such as Lespedeza cuneata (Fabaceae), Salix X sepulcralis (Salicaceae) and Robinia pseudoacacia (Fabaceae).

Our online search on medicinal plants used against onchocerciasis found nine publications since 2002, where a total of 17 plant species, belonging to 10 different families, have been studied. In these studies, only five pure compounds were isolated (Table 1). 
Table 1. List of medicinal plants, products and active compounds known to have antifilarial properties.

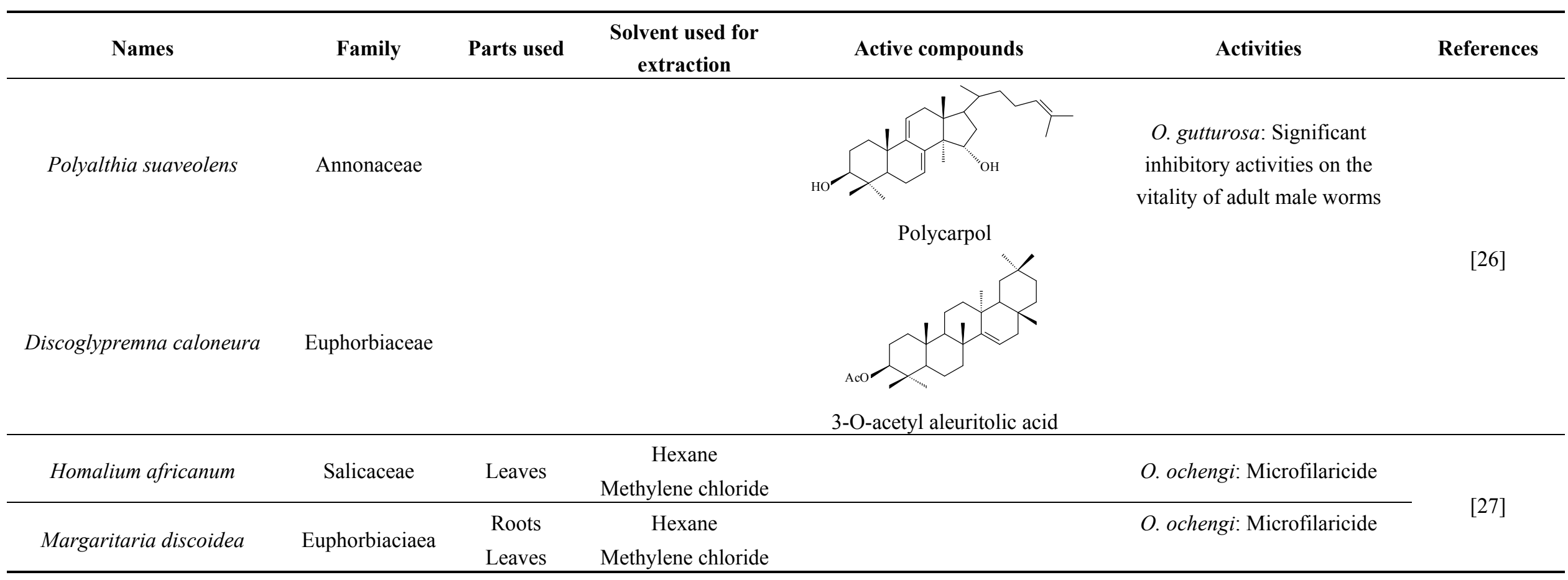


Table 1. Cont.

\begin{tabular}{|c|c|c|c|c|c|c|}
\hline Names & Family & Parts used & $\begin{array}{c}\text { Solvent used for } \\
\text { extraction }\end{array}$ & Active compounds & Activities & References \\
\hline Anogeissus leiocarpus & Combretaceae & Bark, leaves & Ethanol & Gentisic acid & $\begin{array}{l}\text { O. ochengi: Microfilaricide and } \\
\text { macrofilaricide. } \\
\text { C. elegans: High activity on } \\
\text { adults and larvae }\end{array}$ & {$[28,29]$} \\
\hline Khaya senegalensis & Meliaceae & Bark, leaves & Ethanol & & $\begin{array}{l}\text { O. ochengi: Microfilaricide and } \\
\text { macrofilaricide. } \\
\text { C. elegans: Moderate activity on } \\
\text { adults and larvae }\end{array}$ & {$[28]$} \\
\hline Euphorbia hirta & Euphorbiaciaea & Leaves & Ethanol & & $\begin{array}{c}\text { C. elegans: Moderate activity on } \\
\text { adults and larvae }\end{array}$ & \\
\hline Parquetina nigrescens & Asclepiadaceae & & Water & & & {$[28]$} \\
\hline Annona senegalensis & Annonaceae & & Water & & $\begin{array}{c}\text { C. elegans: Moderate activity on } \\
\text { adults and larvae }\end{array}$ & {$[28]$} \\
\hline Hagenia abyssinica & Rosaceae & $\begin{array}{l}\text { Female } \\
\text { flowers }\end{array}$ & $80 \%$ Methanol & & & {$[32]$} \\
\hline
\end{tabular}


Table 1. Cont.

\begin{tabular}{|c|c|c|c|c|c|c|}
\hline Names & Family & Parts used & $\begin{array}{c}\text { Solvent used for } \\
\text { extraction }\end{array}$ & Active compounds & Activities & References \\
\hline Acer rubrum & Aceraceae & \multirow{4}{*}{ Leaves } & \multirow{4}{*}{$70 \%$ Acetone } & & \multirow{4}{*}{$\begin{array}{c}\text { C. elegans: Moderate activity on } \\
\text { adults and larvae }\end{array}$} & \multirow{4}{*}[33]{} \\
\hline Rosa multiflora & Rosaceae & & & & & \\
\hline Quercus alba & Fagaceae & & & & & \\
\hline Rhus typhina & Anacardiaceae & & & & & \\
\hline Lespedeza cuneata & Fabaceae & & & & \multirow{3}{*}{$\begin{array}{l}\text { C. elegans: Low activity on } \\
\text { adults and larvae }\end{array}$} & \multirow{5}{*}[34]{} \\
\hline Salix X sepulcralis & Salicaceae & Leaves & $70 \%$ Acetone & & & \\
\hline Robinia pseudoacacia & Fabaceae & \multirow{3}{*}{ Whole alga } & \multirow{3}{*}{$95 \%$ Ethanol } & & & \\
\hline \multirow[t]{2}{*}{ Botryocladia leptopoda } & \multirow[t]{2}{*}{ Rhodymeniaceae } & & & & $\begin{array}{l}\text { L. sigmodontis and } A \text {. viteae: } \\
\text { Adults }\end{array}$ & \\
\hline & & & & & $\begin{array}{c}\text { B. malayi: Macrofilaricide and } \\
\text { sterilization of female }\end{array}$ & \\
\hline Neurolaena lobata & Asteraceae & Leaves & Ethanol & & $\begin{array}{c}\text { B. pahangi: Macrofilaricide and } \\
\text { micrifilaricide }\end{array}$ & {$[35]$} \\
\hline Lantana camara & Verbenaceae & Stem & $95 \%$ Ethanol & & $\begin{array}{c}\text { A. viteae: Microfilaricide } \\
(95.04 \%) \text { and sterilization of } \\
\text { female }(60.66 \%) \\
\text { B. malayi: Mastomys coucha } \\
\text { killed } 43.05 \% \text { of the adult and } \\
\text { sterilized } 76 \% \text { females }\end{array}$ & {$[36]$} \\
\hline
\end{tabular}


Table 1. Cont

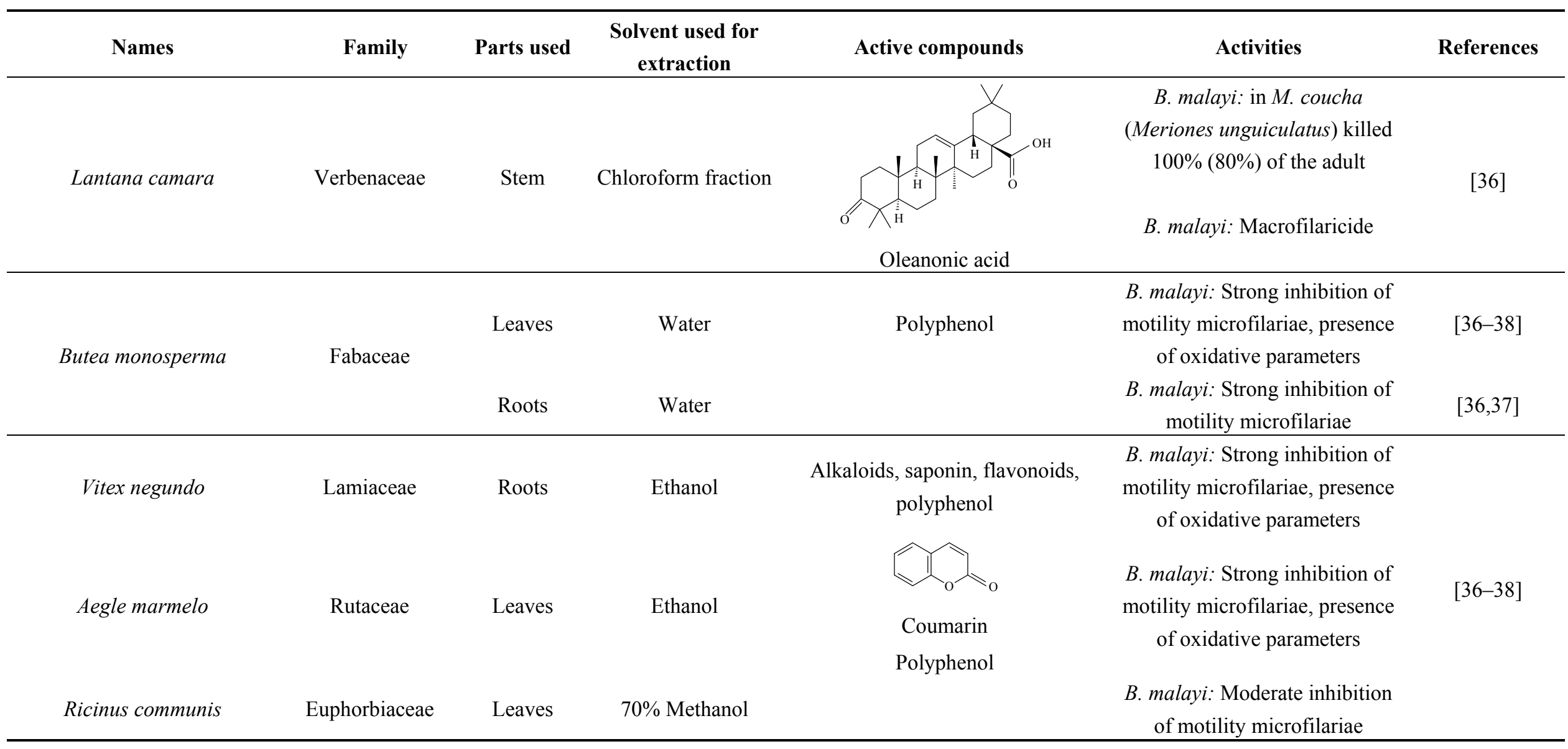


Table 1. Cont.

\begin{tabular}{|c|c|c|c|c|c|c|}
\hline Names & Family & Parts used & $\begin{array}{c}\text { Solvent used for } \\
\text { extraction }\end{array}$ & Active compounds & Activities & References \\
\hline Caesalpinia bonducella & Caesalpiniaceae & $\begin{array}{c}\text { Seed } \\
\text { kernel }\end{array}$ & 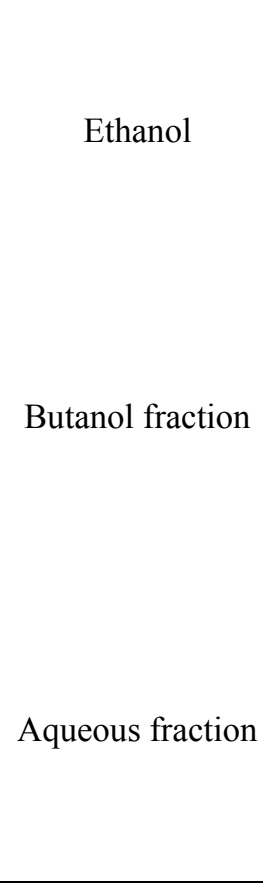 & 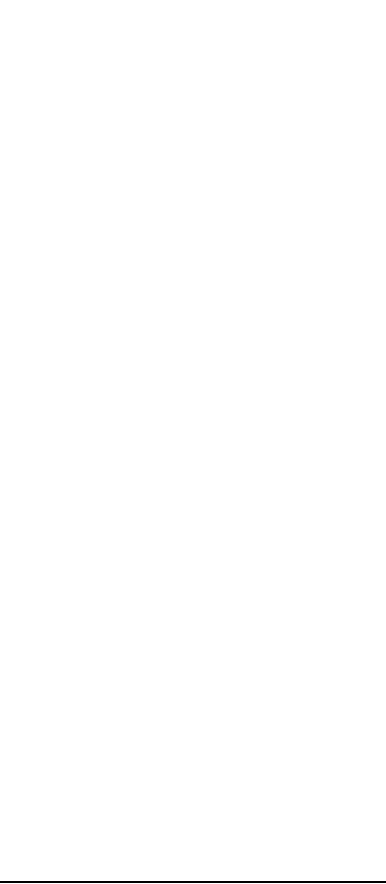 & $\begin{array}{l}\text { L. sigmodontis in cotton rats } \\
\text { S. hispidus: Reduction to up to } \\
96 \% \text { filariae and } 100 \% \text { female } \\
\text { sterilization. Microfilaricide in } \\
\text { B. malayi. } \\
\text { L. sigmodontis in cotton rats } \\
\text { S. hispidus: Reduction to up to } \\
73.7 \% \text { microfilariae. } 82.5 \% \\
\text { mortality of macrofilaria and } \\
100 \% \text { female sterilization. } \\
\text { Microfilaricide in B. malayi. } \\
\text { L. sigmodontis in cotton rats } \\
\text { S. hispidus: Reduction to up to } \\
90 \% \text { microfilariae. } 82.5 \% \\
\text { mortality of macrofilaria and } \\
\text { 100\% female sterilization. } \\
\text { Microfilaricide in B. malayi. }\end{array}$ & [39] \\
\hline Trachyspermum ammi & Apiaceae & Fruits & Methanol & Phenolic monoterpene & $\begin{array}{l}\text { S. digitata: Macrofilaricide } \\
\text { B. malayi: Macrofilaricide and } \\
\text { females sterilization }\end{array}$ & {$[40]$} \\
\hline Piper betle & Piperaceae & Leaves & Methanol & $\begin{array}{l}\text { n-Hexane and chloroform } \\
\text { fractions }\end{array}$ & $\begin{array}{c}\text { B. malayi: Microfilaricide, } \\
\text { moderate activity on } \\
\text { macrofilariae and female } \\
\text { sterilization. } \\
\text { Immunomodulatory properties } \\
\text { in mices }\end{array}$ & [41] \\
\hline
\end{tabular}


Table 1. Cont.

\begin{tabular}{|c|c|c|c|c|c|c|}
\hline Names & Family & Parts used & $\begin{array}{c}\text { Solvent used for } \\
\text { extraction }\end{array}$ & Active compounds & Activities & References \\
\hline Xylocarpus granatum & Meliaceae & Fruits & $50 \%$ Ethanol & $\begin{array}{l}\mathrm{Me} \\
\text { Photogedunin }\end{array}$ & $\begin{array}{c}\text { B. malayi: Excellent } \\
\text { microfilaricidal and } \\
\text { macrofilaricidal efficacies }\end{array}$ & {$[42,43]$} \\
\hline Bauhinia racemosa & Caesalpinaeceae & Leaves & $95 \%$ Ethanol & Galactolipid 1 & $\begin{array}{l}\text { B. malayi: In vivo and in } \\
\text { vitro antifilarial activity }\end{array}$ & {$[44]$} \\
\hline
\end{tabular}


Table 1. Cont.

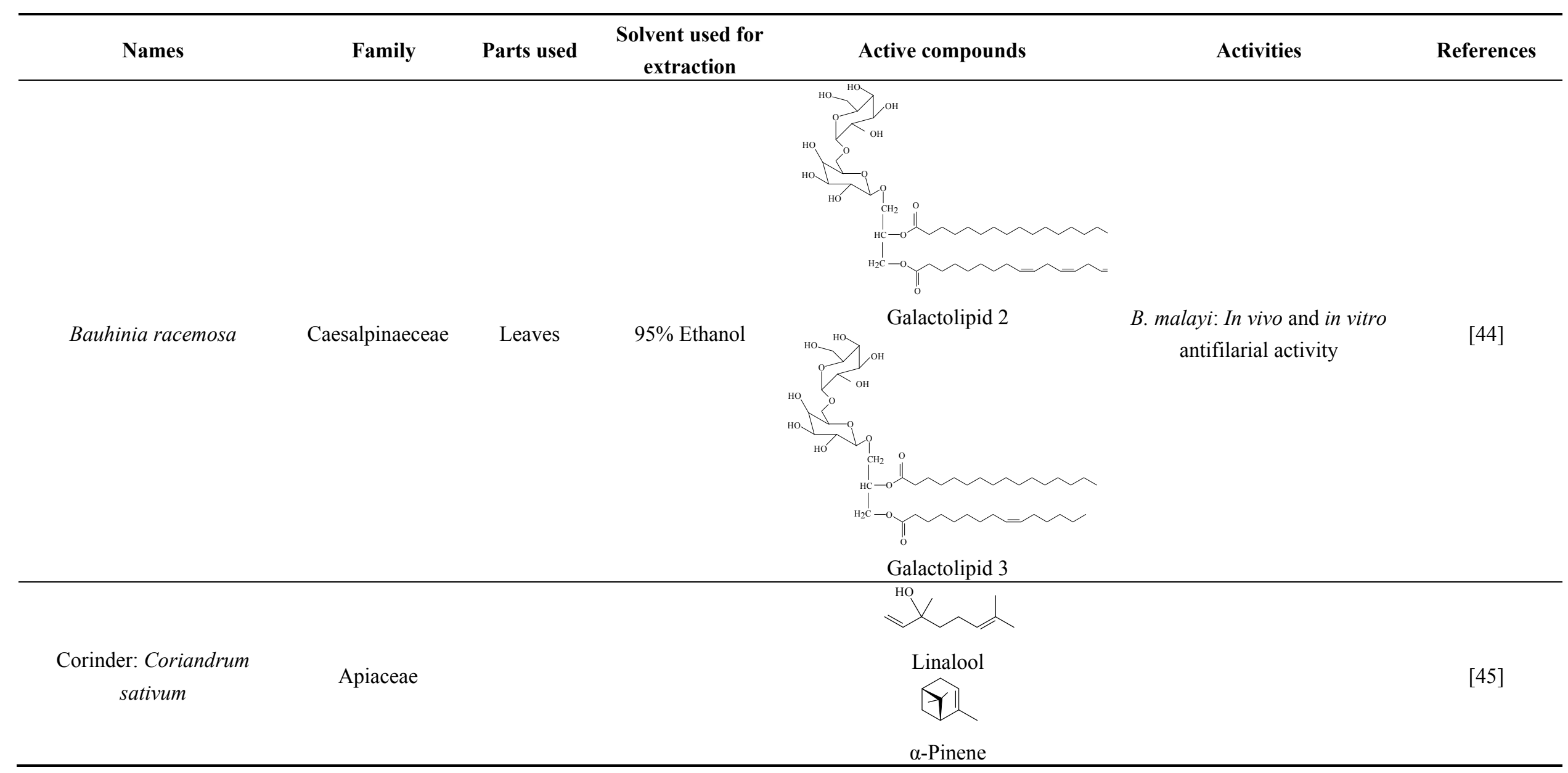


Table 1. Cont.

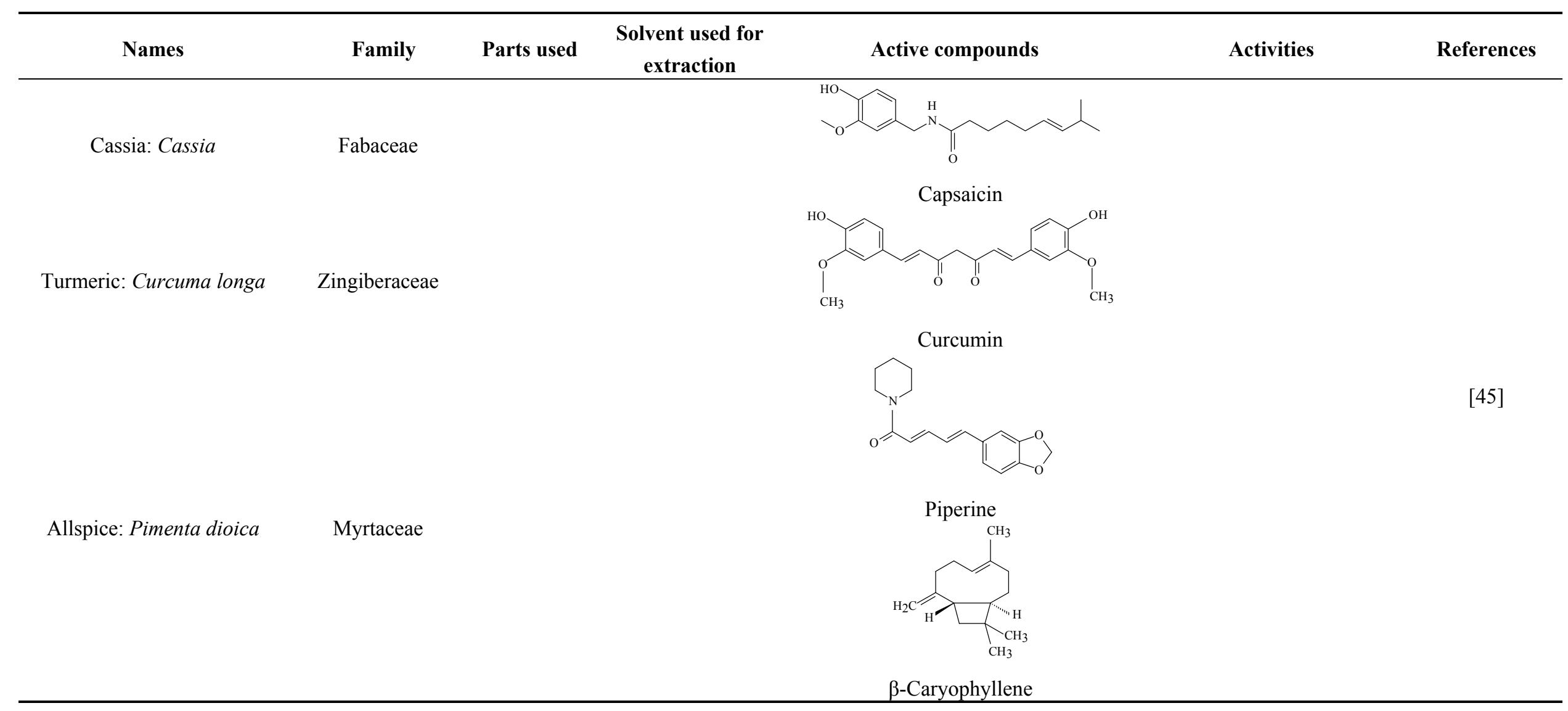


Table 1. Cont.

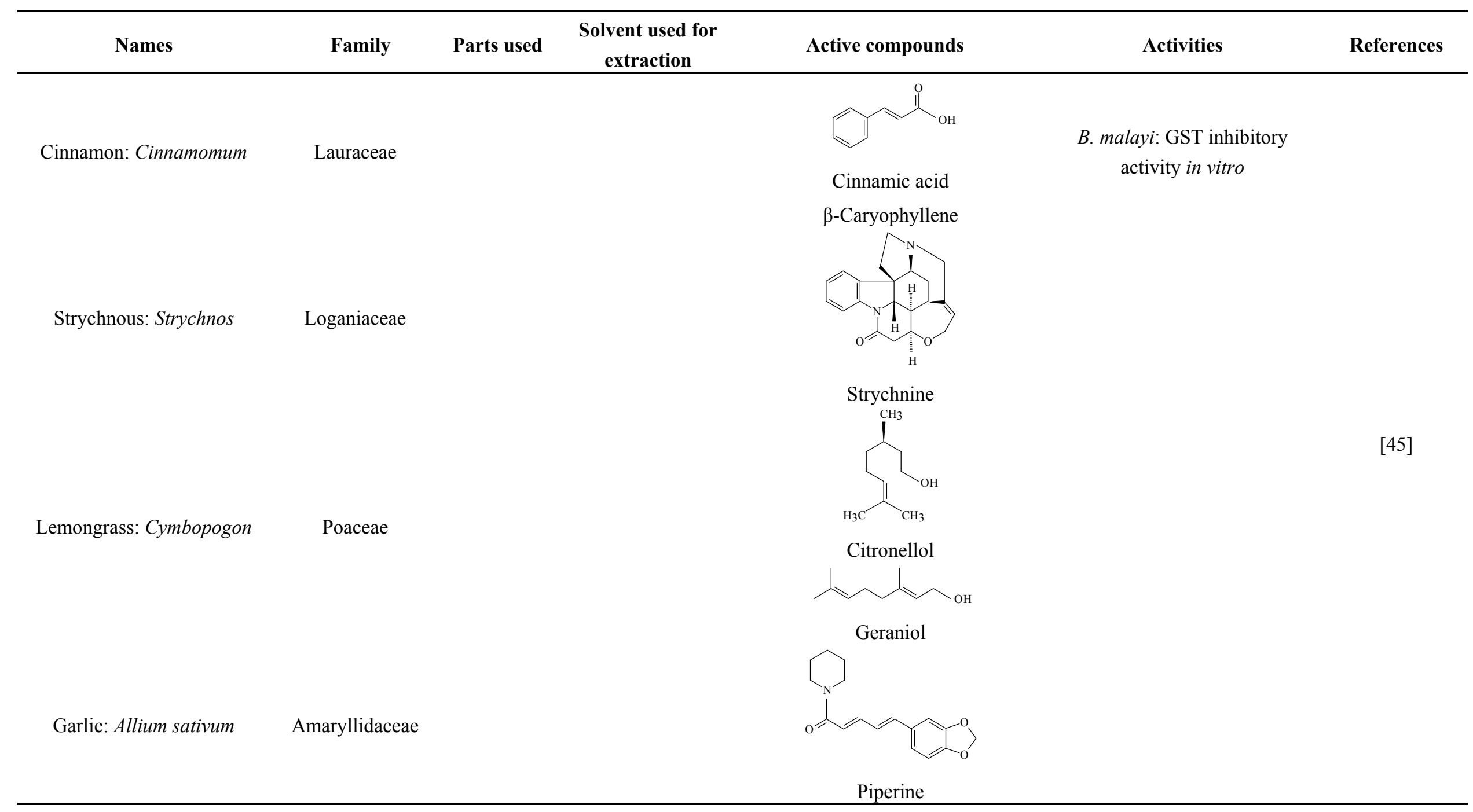


Table 1. Cont.

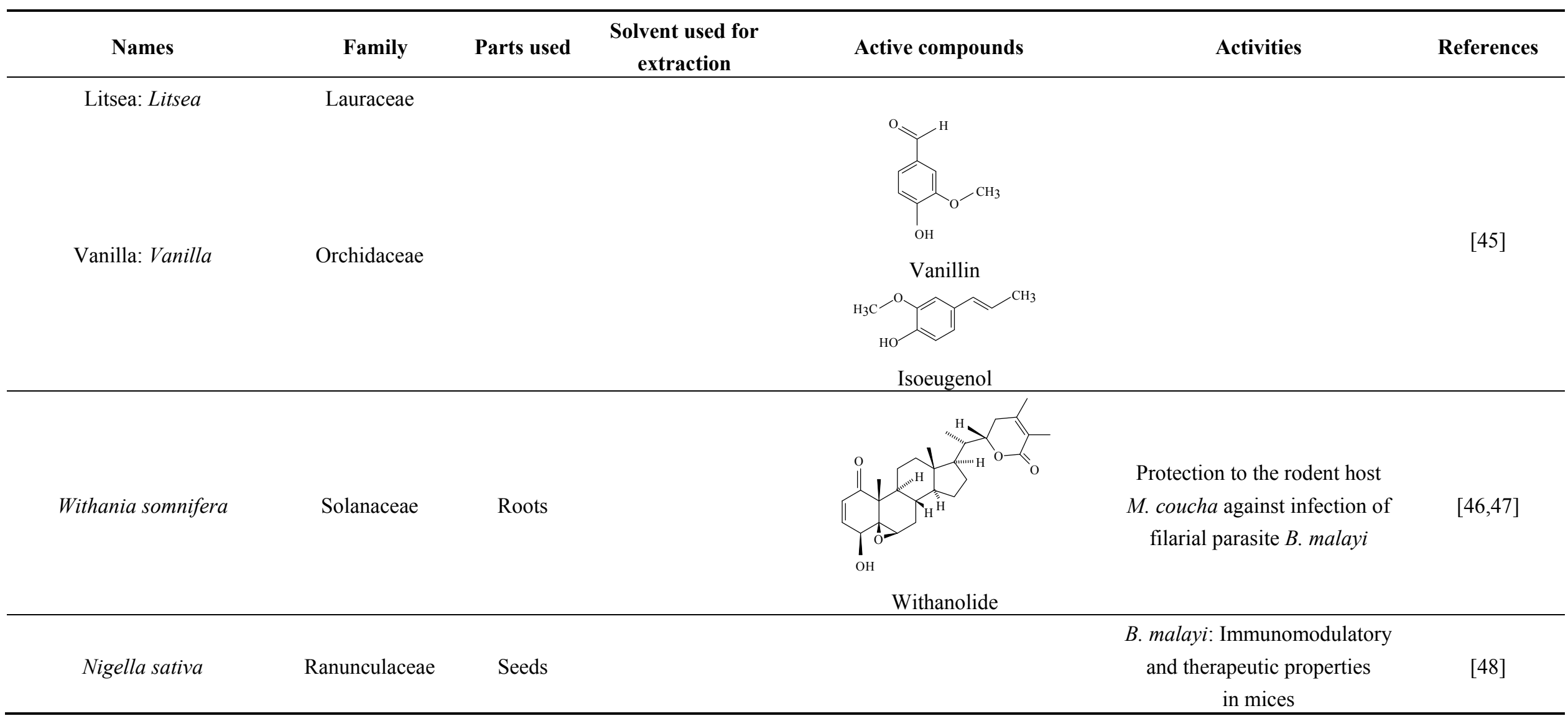

Galactolipid 1: (2S)-1, 2-di-O-linolenoyl-3-O-a-galactopyra-nosyl-(1/6)-O-b-galactopy-ranosyl glycerol; Galactolipid 2: (2S)-1-O-linolenoyl-2-O-palmitoyl-3-O- $a$-galacto-pyranosyl-(1/6)$O$-b-galactopyranosyl glycerol; Galactolipid 3: (2S)-1-O oleoyl-2-O-palmitoyl-3-O- $a$-galacto-pyranosyl-(1/6)-O-b-galactopyranosyl glycerol. 


\subsubsection{Lymphatic Filariasis}

LF is a parasitic disease that is caused by Brugia sp. and W. bancrofti. Current control programs outside sub-Saharan Africa use DEC plus albendazole or DEC alone, while in Africa ivermectin plus albendazole is used because of contraindications for DEC in patients infected with O. volvulus $[16,17]$. However, there is no effective drug that targets the adult stage of the worms. Based on the observation that filarial worms depend on the endosymbiontic bacteria Wolbachia for metabolic and reproductive activities, doxycycline therapy is suggested by Hoerauf et al. [49] and Taylor et al. [50] for individual drug administration in bancroftian filariasis.

Several plants have been assessed for their antifilarial activity against Brugia sp and $W$. bancrofti. Lakshmi et al. [34] conducted a study on the antifilarial activity of a marine red alga, Botryocladia leptopoda (Rhodymeniaceae) against experimental infections with the rodent filarial parasites Litomosoides sigmodontis and Acanthocheilonema viteae and the human-pathogenic B. malayi. They show that the ethanolic crude extract and its hexane fraction reduce microfilarial levels and kill a significant proportion of the adult worms from L. sigmodontis and A. viteae. In the case of B. malayi, the macrofilaricidal efficacy was much less than that observed in the rodent parasites, but significant sterilization of the surviving female parasites was caused by the hexane and chloroform fractions of the ethanolic crude extract of B. leptopoda.

Fujimaki et al. [35] screened and provided detailed informations about 11 medicinal plants used in Guatemala for in vitro macrofilaricidal activity against B. pahangi. Among the 11 medicinal plants, the ethanolic extract of leaves of Neurolaena lobata (Asteraceae) showed the highest inhibitory activity against the motility of adult worms. The in vitro assay of the extract of $N$. lobata showed potential macro- and micro-filaricidal activities.

Misra et al. [36] reported the antifilarial activity in the extract of stem portions of the plant Lantana camara (Verbenaceae). They showed that the ethanolic crude extract of this plant administered orally to the rodent model Mastomys couch a killed $43.05 \%$ of adult B. malayi and sterilized $76 \%$ of surviving female worms. After fractionation of the ethanolic extract of this Verbenaceae, Misra et al. [36] were able to show that the chloroform fraction contains $34.5 \%$ adulticidal activity along with sterilization of $66 \%$ of female worms. They also demonstrated that the activity of $L$. camara depends on the rodent host. Thus, using Meriones unguiculatus (gerbil) rodents as host for B. malayi, lead to an antifilarial activity up to $80 \%$, whereas at the same dosage, all adult worms were killed using $M$. coucha as host. The authors also reported that $L$. camara is efficient against the $A$. viteae, exerting strong microfilaricidal (95.04\%) and sterilization (60.66\%) efficacy with mild macrofilaricidal action. Two compounds from L. camara, oleanonic acid and oleanolic acid, isolated from hexane and chloroform fractions also showed an in vitro activity against $B$. malayi adults. Toxicity studies of $L$. camara in rats showed that all rats remained active and healthy throughout the study [34].

Sahare et al. [37,51] analyzed the in vitro effect of Butea monosperma (Fabaceae), Vitex negundo (Lamiaceae), Aegle marmelo (Rutaceae) and Ricinus communis (Euphorbiaceae) on the motility of B. malayi microfilariae. They reported that aqueous extract of $B$. monosperma leaves, ethanolic extract of $V$. negundo root and ethanolic extract A. marmelo leaves exhibited a $100 \%$ inhibition of motility of microfilariae at $100 \mathrm{ng} / \mathrm{mL}$ concentration as compared to controls. At the same concentration, methanolic extract of $R$. communis leaves and aqueous extract of B. monosperma roots showed no 
significant activity on the motility of B. malayi microfilaria. Using thin layer chromatography, Sahare et al. [51] were able to reveal the presence of alkaloids, saponin and flavonoids in the roots of $V$. negundo and coumarin in the leaves of $A$. marmelos.

Gaur et al. [39] studied the antifilarial activity of Caesalpinia bonducella (Caesalpiniaceae) seed kernel by using cotton rats Sigmodon hispidus and M. coucha that harbor the filarial parasites L. sigmodontis and B. malayi, respectively. Oral treatment of the rats with ethanolic extract of C. bonducella significantly reduced the number of microfilariae and macrofilariae of L. sigmodontis, with up to $96 \%$ filaricidal activities and $100 \%$ female sterilizing efficacy. Furthermore, Gaur et al. [39] reported that the butanol and the aqueous fraction exerted $73.7 \%$ and $90 \%$ reduction of microfilariae number, respectively, and $82.5 \%$ mortality in adult worms with $100 \%$ female sterilization for both fractions, while two hexane fractions lead to $64 \%$ and $95 \%$ macrofilaricidal activity and $100 \%$ worm sterilization. However, in the B. malayi/M. coucha model, the hexane fraction that demonstrated high macrofilaricidal activity on L. sigmodontis, only showed a gradual microfilaraemia reduction and caused $80 \%$ sterilization of female parasites. These results suggest that $C$. bonducella seed kernel extract and fractions show microfilaricidal, macrofilaricidal and female-sterilizing efficacy against L. sigmodontis and microfilaricidal and female-sterilizing efficacy against B. malayi. This indicates the potential of the plant in providing a lead for new antifilarial drug development [39].

Mathew et al. [40] investigated the in vitro activity of a methanolic extract of fruits of Trachyspermum ammi (Apiaceae) against adult bovine filarial Setaria digitata worms. Using high-performance liquid chromatography, they isolated the active fraction containing a phenolic monoterpene. After characterization, the active molecule showed macrofilaricidal activity and sterilizing efficacy against B. malayi in M. coucha. After extraction of leaves of Piper betle (Piperaceae) in methanol, Singh et al. [41] studied the antifilarial activities of the crude extract, the n-hexane and chloroform fractions of this Piperaceae using B. malayi. They demonstrated that the methanolic crude extract, the hexane and chloroform fractions of $P$. betle in vivo contain remarkable immunomodulatory properties in BALB/c mice and enhance both humoral as well as cell-mediated immune responses. Furthermore, in vivo antifilarial activity of the crude methanol extract and its active fractions was assessed using B. malayi, experimentally maintained in $M$. coucha, and the antifilarial results correlated with the immunomodulation potential of the plant. The crude extract and its active fractions suppressed microfilaraemia, showed moderate adulticidal activity and female worm sterilization.

Sharma et al. [38] selected extracts of roots of Vitex negundo, leaves of Butea monosperma, Aegle marmelos and Ricinus communis, to explore the possible involvement of any oxidative mechanisms in the observed antifilarial effect. They observe the presence of polyphenolic compounds and an increase in oxidative parameters in $V$. negundo, B. monosperma and A. marmelos and conclude that the observed antifilarial action of these herbal extracts might be associated with oxidative stress.

Misra et al. [42] studied the antifilarial activity of fruits of Xylocarpus granatum (Meliaceae) against $B$. malayi in vivo using the jird model M. unguiculatus and $M$. coucha. The in vitro effect of crude aqueous extract from different parts of $X$. granatum on filarial parasites was reported earlier by Zaridah et al. [43]. In their studies, Misra et al. [42] demonstrated that the crude aqueous ethanolic extract was active in vitro and demonstrated a $52.8 \%$ and $62.7 \%$ adulticidal and embryostatic effect on B. malayi in vivo, transplanted in the jird model (M. unguiculatus) and M. caucha. After fractionation 
(ethyl acetate fraction, n-butanol fraction, water-soluble fraction and water-insoluble fraction), only the ethyl acetate fraction revealed in vivo activity. Eight pure molecules were isolated from the active fraction, with the two compounds gedunin $\left(\mathrm{IC}_{50}=0.239 \mu \mathrm{g} / \mathrm{mL}, \mathrm{SI}=889.1\right)$ and photogedunin $\left(\mathrm{IC}_{50}=0.213 \mu \mathrm{g} / \mathrm{mL}, \mathrm{SI}=1231.4\right)$ at $5 \times 100 \mathrm{mg} / \mathrm{kg}$ by subcutaneous route revealed adulticidal efficacy, with $80 \%$ and $70 \%$ mortality of the transplanted B. malayi.

Sashidhara et al. [44] isolated galactolipid from Bauhinia racemosa (Caesalpinaeceae). They showed that the leaves of $B$. racemosa exhibit promising in vitro and in vivo antifilarial activity against $B$. malayi which can be attributed to the presence of one pure compound, namely (2S)-1,2-di- $O$-linolenoyl-3- $O$ - $a$-galactopyranosyl-(1/6)- $O$ - $b$-galactopy ranosyl glycerol.

Azeez et al. [45] identified 10 spices and medicinal plants, namely coriander (Coriandrum sativum, Apiaceae), cassia (Cassia, Fabaceae), turmeric (Curcuma longa, Zingiberaceae), allspice (Pimenta dioica, Myrtaceae), cinnamon (Cinnamomum, Lauraceae), strychnous (Strychnos, Loganiaceae), lemongrass (Cymbopogon, Poaceae), garlic (Allium sativum, Amaryllidaceae), litsea (Litsea, Lauraceae) and vanilla (Vanilla, Orchidaceae) that contain phytochemicals, with the potential to inhibit the detoxification enzyme glutathione S-transferase (GST) from B. malayi. Molecular docking of these compounds, followed by in vitro GST assay, demonstrated that linalool, alpha-pinene, strychnine, vanillin, piperine, isoeugenol, curcumin, beta-caryophyllene, cinnamic acid, capsaicin, citronellol and geraniol effectively inhibit the B. malayi GST and therefore mark them as lead compounds.

Kushwaha et al. [46] reported that chemotypical variations in Withania somnifera (Solanaceae) lead to differentially modulated immune responses in BALB/c mice. Furthermore, the published findings [48] on the different immunomodulatory and immunotherapeutic potentials for the crude oil of Nigella sativa (Ranunculaceae) seeds and its active ingredients led Kushwaha et al. [47] to hypothesize that immunostimulation prior to pathogen invasion might provide protection against filarial infection. They demonstrated that crude root extracts of chemotypes NMITLI-101 (101R), NMITLI-118 (118R) and NMITLI-128 (128R) as well as withanolide withaferin A of W. somnifera offer protection to the rodent host $M$. coucha against infection of filarial parasite B. malayi. They also showed that treatment with $W$. somnifera extracts negatively affected not only larval establishment in the host but also led to a defective embryogenesis in female worms. This study revealed the potent immunoprophylactic property of $W$. somnifera.

Our online search on medicinal plants used against LF found 16 publications since 2002, where a total of 24 plant species, belonging to 20 different families, have been studied on. In these studies 24 pure compounds were isolated (Table 1).

\subsection{Schistosomiasis}

Schistosomiasis (also known as bilharzia, bilharziosis or snail fever) is a chronic parasitic disease caused by trematode parasites of the genus Schistosoma. Schistosomiasis is endemic in 77 countries, with higher prevalence in the tropical and the subtropical belt of the globe [52]. Is it estimated that about 800 million people are at risk of infection due to their exposure to contaminated water and 390-600 million people are infected with these parasites [52-55]. There are two main clinical forms of schistosomiasis: the intestinal form, which is caused by five different species ( $S$. mansoni, 
S. japonicum, S. mekongi, S. guineensis, $S$. intercalatum) and the urogenital form, which is caused by S. haematobium [56].

The infection of Schistosoma sp. occurs when the larvae of the parasites are liberated by the infected snail (intermediary host), get in contact with the human host and subsequently penetrate the skin. Once inside the human hosts, the pathogens differentiate into schistosomules, which migrate via the bloodstream to the liver and develop into male and female mature forms. After mating, the worms migrate again and relocate at the mesenteric intestinal veins or the venous plexus of the urinary system. The females release the eggs, which are able to pass epithel of the blood vessels and reach the intestinal lumen, the bladder or urethra lumen in order to be expelled by feces or urine. Some of these eggs also remain in these tissues. The damage of blood vessels, together with immune reactions against the retained eggs are responsible for the clinical forms of schistosomiasis.

The first approaches towards controlling the infection were initiated in the beginning of the 20th century; however, there is still no consensus about the best strategy for controlling this disease [57]. Traditionally, the main prevention and control strategies are based on the control of the transmitting snails of the genus Biomphalaria, improving the sanitation conditions and the treatment of patients $[56,58,59]$. It is generally agreed that no individual method is sufficient to block transmission. Consequently, combinatory approaches are considered for interruption of the life cycle of Schistosoma sp. [54,60-62].

Currently, a main strategy to control schistosomiasis is based on the periodic treatment of people living at risk areas with anti-schistosomicidal drugs in order to reduce morbidity and transmission [63]. Moreover, it was recently suggested that schistosomiasis, as well as some other neglected diseases could be controlled by large scale treatment of the whole population with safe and efficient drugs in areas endemic for more than one parasitic disease [63].

\subsubsection{Currently Available Drugs for the Treatment of Schistosomiasis}

In former times, chemotherapy against Schistosoma sp. infection depended on antimonials. Due to serious side effect caused by these drugs, the use as schistosomicidal drugs was discontinued and currently the treatment mainly relies on three compounds: metrifonate, oxamniquine and praziquantel $[64,65]$.

\subsubsection{Metrifonate}

Metrifonate (O,O-dimetil-2,2,2-tricloro-1-hydroxyethylphosphonate) was derived from an organophosphorus insecticide (dimethyl(2,2,2-trichloro-1-hydroxyethyl phosphonate). Metrifonate is a reversible inhibitor of the acetylcholinesterase, the enzyme that is responsible for acetylcholine catabolism. This inhibitory activity at low concentrations causes a selective paralysis of the parasite's muscles, making it susceptible of being carried out by the bloodstream to the liver (in case of S. mansoni) or to the lungs (in case of S. haematobium). Since high concentrations of metrifonate are toxic for humans due to the diminished level of erythrocitary cholinesterase activity, the use is restricted to 3 doses. Recent results indicate that following the reduction of the concentration of the drug, $S$. mansoni is able to go back to the mesenteric veins within the intestine and re-establish the infection. However, S. haematobium adults remain in the lung and are not able to move back to the 
bladder or urethra veins and re-establish the infection [66,67]. Since metrifonate is only effective against the urogenital disease, the drug is only recommended by the WHO to treat the infection of S. haematobium [68].

\subsubsection{Oxamniquine}

Oxamniquine (1,2,3,4-tetrahydro-2-[isopropylamino]methyl(-)7-nitro-6-nitro-quinoline methanol) was reported to be substrate of a sulfotransferase that produces an ester which is able to react with nucleic acids and thereby interferes with replication and transcription processes. This drug also causes an increased motility and tegument damage, which primarily affects male worms. S. mansoni is more susceptible to the drug than other species. Under the effect of the drug, the male worm migrates into the liver, where the cellular immune response eliminates the pathogen. Deleterious changes are also observed in females. However, they are mostly due to the lack of male stimulation rather than to a direct effect of the drug. The absence of a human homologue renders oxamniquine effective with a low cyto-toxicity profile to human cells [69]. However, the emergence of resistant strains combined with high production cost and its restricted use for $S$. mansoni, makes the drug unusable for control campaigns.

\subsubsection{Praziquantel}

Praziquantel (2-(cyclohexylearbonil-1,2,3,6,7,11-hexylhydro-4H-pyrazino[2,1-a]isoquinil-4-one) is the only drug presently available for the treatment of the three human pathogenic species of Schistosoma (S. mansoni, S. haematobium and S. japonicum). The mechanism of action is not yet well established. It was proposed that the drug induces membrane alterations, producing a $\mathrm{Ca}^{2+}$ entry in the muscle cells and a paralysis in the contracted state. The paralyzed parasites are then carried out by the bloodstream [70-72]. The drug also causes tegumental damage allowing the host-immune cells to reach the interior of the parasite and to eliminate it [73,74]. The drug is mainly active against the adult forms of the parasite, limiting its use against the early stages of the infection [74,75]. Praziquantel is a safe and low cost drug, and it has been used in the last 20 years for control strategies and patients' treatment in countries such as Brazil, Cambodia, China, Egypt, Morocco and Saudi Arabia [76-78]. However, due to its use at large scale control programs, the emergency of resistance and diminished efficacy were reported [68,79-89].

In search for new lead compounds, the richness of chemical structures of metabolites available in nature is also being exploited. The identification of natural products (mainly derived from plants) with schistosomicidal activity is a valuable strategy for obtaining lead compounds to combat this health problem [90-92].

\subsubsection{Natural Products for the Control of Schistosomiasis}

Vegetable oil extracts probably constitute the first anthelmintic products in traditional medicine. The variety of their application modes evidenced the ethno-pharmacological potential of these extracts as sources of active compounds. However, there are only a few studies which are focusing on the isolation, the identification, and eventually the validation of the active molecules within the plant 
extracts [93-98]. More recently, an initiative of research groups all over the world has been founded to set up plant extract screening programs [99-103]. A variety of compounds that reveal schistosomicidal activity have been identified in in vitro assays (Table 2). However, the extrapolation of in vitro results to the "in vivo world" is far away from being trivial. A good example for this is Vernodalin (Table 2), a sesquiterpene lactone with a promising in vitro activity but no in vivo activity [104]. Even after promising results are obtained in in vivo studies, the application of this drug in an endemic region must take other factors into consideration, such as the presence of other infectious pathogens. These could cause co-infections and thereby interfere with the respective treatment. For example, the antimalarial activity of Artemisinin and some derivatives has been exploited for more than 20 years [105]. More recently, the discovery and in vivo validation of schistosomicidal activity of artemisinin was established by observing a reduction of the parasitaemia in experimentally $S$. japonicum infected mice and the susceptibility of schistosomula to the drug [106-108]. Later, these results were also confirmed for $S$. mansoni. Within this study, an increased sensitivity of the females to the drug was also observed [109]. Although these results were promising, the use of artemisinin in regions endemic for malaria should be carefully assessed, since the application of this drug to control schistosomiasis could have the serious adverse side effect of increasing artemisinin drug resistance in malaria [110,111].

\subsubsection{Mode of Action and Molecular Targets in Schistosoma}

Synthetic drugs and natural compounds with schistosomicidal activity in general lead to alterations in their behavior (disruption of mating of males and females, reduction in reproductive fitness), in the morphology or constitution of the protective tegument, or in the muscle activity of the parasite.

\subsubsection{Compounds that Disrupt Mating}

Compounds such as curcumin, artesunate, artemeter, artemisina, vernodalin, piplartina, as well as avocado and soybean unsaponifiable oils, essential oils from Plectranthus neochilus and extracts from Calyptridium umbellatum cause the separation of males and females (Table 2). The mated state is a fundamental process of the parasite viability inside the human host and for establishing the infection. Only when the parasites are mated (the female is held in a groove within the male body, the gynecophoric canal) the sexual maturation and egg production occurs. The induction of separation of males and females reduces or even arrests the release of eggs, which is a relevant factor in the hepatic pathology and the transmission of the disease [112]. 
Table 2. List of medicinal plants, products and active compounds known to have anti-schistosomal properties.

\begin{tabular}{|c|c|c|c|c|c|c|c|}
\hline \multirow{2}{*}{ Compounds / Substances } & \multirow{2}{*}{ Origin } & \multicolumn{3}{|c|}{ Schistosomicidal activities } & \multicolumn{2}{|c|}{ Assays } & \multirow{2}{*}{ References } \\
\hline & & in vitro & in vivo & Observations & Toxicity & Clinical & \\
\hline Curcumin & Curcuma longa & $\begin{array}{l}\text { S. mansoni adult- } \\
50 \mu \mathrm{M}(100 \% \\
\text { mortality in male and } \\
\text { female })\end{array}$ & $\begin{array}{c}400 \mathrm{mg} / \mathrm{Kg} \text { in mouse }{ }^{1}- \\
43.5 \% \text { mortality in male } \\
\text { and } 4.6 \% \text { in female of } \\
\text { S. mansoni) }\end{array}$ & $\begin{array}{l}\text { Reduction in the } \\
\text { oviposition } \\
\text { Induced separation of } \\
\text { males and females } \\
\text { Reduction in the motor } \\
\text { activity }\end{array}$ & nd & nd & {$[99,113]$} \\
\hline $\begin{array}{c}\text { Essencial oil } \\
\text { (sesquiterpenes } 57.20 \% \text { and } \\
\text { monoterpenes } 42.13 \% \text { ) }\end{array}$ & $\begin{array}{c}\text { Plectranthus } \\
\text { neochilus }\end{array}$ & $\begin{array}{c}\text { S. mansoni adult- } \\
\text { LC }_{50} \text {-value } \\
89.65 \mathrm{mg} / \mathrm{mL} \text { at } 24 \mathrm{~h} \\
\mathrm{LC}_{50} \text {-value } \\
58.18 \mathrm{mg} / \mathrm{mL} \text { at } 120 \mathrm{~h}\end{array}$ & nd & $\begin{array}{l}\text { Reduction in the } \\
\text { oviposition } \\
\text { Induced separation of } \\
\text { males and females } \\
\text { Reduction in the motor } \\
\text { activity }\end{array}$ & $\begin{array}{c}\text { Non-toxic in V79 } \\
\text { cells }^{2} \\
\text { (concentrations } \\
\text { lower than } \\
200 \mu \mathrm{g} / \mathrm{mL} \text { ) }\end{array}$ & nd & [101] \\
\hline 2-hydroxychrysophanol & $\begin{array}{l}\text { Hemerocallis } \\
\text { fulva }\end{array}$ & $\begin{array}{c}\text { S. mansoni adult- } \\
50 \mu \mathrm{g} / \mathrm{mL}(35 \% \\
\text { mortality in male and } \\
\text { female) } \\
\text { Schistosomula- } \\
25 \mu \mathrm{g} / \mathrm{mL}(80 \% \\
\text { mortality) }\end{array}$ & nd & nd & nd & nd & {$[114]$} \\
\hline Kwanzoquinone E & $\begin{array}{l}\text { Hemerocallis } \\
\qquad \text { fulva }\end{array}$ & $\begin{array}{c}\text { S. mansoni adult- } \\
50 \mu \mathrm{g} / \mathrm{mL}(55 \% \\
\text { mortality in male and } \\
\text { female) } \\
\text { Schistosomula- } \\
25 \mu \mathrm{g} / \mathrm{mL}(100 \% \\
\text { mortality) }\end{array}$ & nd & nd & nd & nd & {$[114]$} \\
\hline
\end{tabular}


Table 2. Cont.

\begin{tabular}{|c|c|c|c|c|c|c|c|}
\hline \multirow{2}{*}{ Compounds / Substances } & \multirow{2}{*}{ Origin } & \multicolumn{3}{|c|}{ Schistosomicidal activities } & \multicolumn{2}{|c|}{ Assays } & \multirow{2}{*}{ References } \\
\hline & & in vitro & in vivo & Observations & Toxicity & Clinical & \\
\hline $\begin{array}{lll}1 & 11\end{array}$ & Schefflera vinosa & $\begin{array}{l}\text { S. mansoni adult- } \\
100 \mu \mathrm{M}(25 \% \\
\text { mortality in male and } \\
\text { female })\end{array}$ & nd & $\begin{array}{l}\text { Reduction in the Motor } \\
\text { activity }\end{array}$ & nd & nd & [98] \\
\hline \multicolumn{8}{|l|}{ Quercetin 3-O- $\beta$-D-rhamnoside } \\
\hline \multicolumn{8}{|c|}{$\begin{array}{l}\text { Doses of } 0.31 \mathrm{~g} \mathrm{~kg}^{-1} \text { for } \\
21 \text { days }-32.46 \% \\
\text { reduction of } S . \text { mansoni } \\
\text { in mice }\end{array}$} \\
\hline Aqueous leaves extract & $\begin{array}{l}\text { Clerodendrum } \\
\text { umbellatum }\end{array}$ & $\mathrm{Nd}$ & $\begin{array}{c}80 \mathrm{mg} / \mathrm{kg} \text { in mice }{ }^{4}- \\
100 \% \text { mortality in } \\
\text { S. mansoni }\end{array}$ & $\begin{array}{c}\text { Reduction in the } \\
\text { oviposition } \\
\text { (75.49\% released eggs } \\
\text { in faeces) }\end{array}$ & nd & nd & [116] \\
\hline Artesunate & Artemisia annua & $\begin{array}{l}\text { S. mekongi adult- } \\
40 \mu \mathrm{g} / \mathrm{mL}(100 \% \\
\text { mortality in male and } \\
\text { female) } \\
\text { S. mansoni adult- } \\
40 \mu \mathrm{g} / \mathrm{mL}(80 \% \\
\text { mortality in male and } \\
\text { female) }\end{array}$ & $\begin{array}{l}150 \text { to } 300 \mathrm{mg} / \mathrm{kg} \text { in } \\
\text { mice- } 67 \text { and } 77 \% \\
\text { mortality in male and } \\
\text { female) }\end{array}$ & $\begin{array}{l}\text { Reduction in the motor } \\
\text { activity } \\
\text { Reduction in the } \\
\text { oviposition } \\
\text { Tegumental disruption }\end{array}$ & nd & nd & {$[117,118]$} \\
\hline
\end{tabular}


Table 2. Cont.

\begin{tabular}{|c|c|c|c|c|c|c|c|}
\hline \multirow{2}{*}{ Compounds / Substances } & \multirow{2}{*}{ Origin } & \multicolumn{3}{|c|}{ Schistosomicidal activities } & \multicolumn{2}{|c|}{ Assays } & \multirow{2}{*}{ References } \\
\hline & & in vitro & in vivo & Observations & Toxicity & Clinical & \\
\hline Artemether & Artemisia annua & $\mathrm{Nd}$ & $\begin{array}{c}50 \mathrm{mg} / \mathrm{Kg} \text { in mice }{ }^{5}- \\
\text { reduction of } S \text {. mansoni } \\
\text { female } \\
100 \mathrm{mg} / \mathrm{Kg} \text { in mice- } \\
61.5 \% \text { mortality in } \\
\text { S. mansoni female } \\
150 \text { to } 300 \mathrm{mg} / \mathrm{kg} \text { in } \\
\text { mice- } 88 \text { and } 97 \% \\
\text { mortality in } S . \text { mansoni } \\
\text { male and female } \\
10 \mathrm{mg} / \mathrm{Kg} \text { in rabbit }{ }^{6} \text { - } \\
97 \% \text { mortality in } \\
S . \text { japonicum } \\
\text { male and female } \\
10 \mathrm{mg} / \text { Kg in dog }{ }^{6} \text { - } \\
99.3 \% \text { mortality in } \\
\text { S. japonicum } \\
\text { male and female }\end{array}$ & $\begin{array}{l}\text { Reduced liver and } \\
\text { spleen weight of } \\
\text { treated animals } \\
\text { Reduction in the motor } \\
\text { activity } \\
\text { Tegumental disruption } \\
\text { Alteration of the } \\
\text { reproductive organs, } \\
\text { ovarian volume } \\
\text { reduction and } \\
\text { depigmentation of the } \\
\text { intestinal parasites } \\
\text { portion }\end{array}$ & nd & $\begin{array}{c}30 \mathrm{mg} / \mathrm{kg} \\
(2 \text { oral } \\
\text { doses })\end{array}$ & $\begin{array}{l}{[109,110} \\
118-120]\end{array}$ \\
\hline & $\begin{array}{c}\text { Vernonia } \\
\text { amygdalina }\end{array}$ & $\begin{array}{c}\text { S. japonicum adult - } \\
20 \mu \mathrm{g} / \mathrm{mL}(100 \% \\
\text { immobilization and } \\
\text { oviposition) }\end{array}$ & $\begin{array}{l}2.5 \mathrm{mg} / \mathrm{kg} \text { in mice }- \text { no } \\
\text { mortality S. japonicum }\end{array}$ & $\begin{array}{l}\text { Inhibition of the } \\
\text { oviposition } \\
\text { Inhibition of the motor } \\
\text { activity }\end{array}$ & $\begin{array}{c}\text { Toxic in } \mathrm{KB} \text {, } \\
\text { P-388 } \\
\text { L-1210 cells }{ }^{7} \text { at } \\
120 \mathrm{mg} / \mathrm{Kg}\end{array}$ & nd & [104] \\
\hline Vernodalin & & & & & & & \\
\hline
\end{tabular}


Table 2. Cont.

\begin{tabular}{|c|c|c|c|c|c|c|c|}
\hline \multirow{2}{*}{ Compounds / Substances } & \multirow{2}{*}{ Origin } & \multicolumn{3}{|c|}{ Schistosomicidal activities } & \multicolumn{2}{|c|}{ Assays } & \multirow{2}{*}{ References } \\
\hline & & in vitro & in vivo & Observations & Toxicity & Clinical & \\
\hline Aspidin & Dryopteris spp. & $\begin{array}{l}\text { S. mansoni adult- } \\
25 \mu \mathrm{M}(100 \% \\
\text { mortality in male and } \\
\text { female })\end{array}$ & nd & $\begin{array}{l}\text { Reduction in the motor } \\
\text { activity } \\
\text { Tegumental alterations }\end{array}$ & nd & nd & {$[100]$} \\
\hline Favaspi & Dryopteris spp. & $\begin{array}{l}\text { S. mansoni adult- } \\
50 \mu \mathrm{M}(100 \% \\
\text { mortality in male and } \\
\text { female })\end{array}$ & nd & $\begin{array}{l}\text { Reduction in motor the } \\
\text { activity } \\
\text { Tegumental alterations }\end{array}$ & nd & nd & {$[100]$} \\
\hline Methylene-bis-aspidinol & Dryopteris $s p p$. & $\begin{array}{c}\text { S. mansoni adult- } \\
100 \mu \mathrm{M}(100 \% \\
\text { mortality in male and } \\
\text { female })\end{array}$ & nd & $\begin{array}{l}\text { Reduction in the motor } \\
\text { activity }\end{array}$ & nd & nd & {$[100]$} \\
\hline Desaspidin & Dryopteris spp. & $\begin{array}{l}\text { S. mansoni adult- } \\
25 \mu \mathrm{M}(100 \% \\
\text { mortality in male and } \\
\text { female })\end{array}$ & nd & $\begin{array}{l}\text { Reduction in the motor } \\
\text { activity }\end{array}$ & nd & nd & {$[100]$} \\
\hline Piplartine & $\begin{array}{c}\text { Piper } \\
\text { tuberculatum }\end{array}$ & $\begin{array}{c}\text { S. mansoni adult- } \\
15.8 \mu \mathrm{M}(100 \% \\
\text { mortality in male and } \\
\text { female }) \\
\text { Schistosomula }-5 \mu \mathrm{M} \\
\quad(100 \% \text { mortality })\end{array}$ & nd & $\begin{array}{l}\text { Reduction in the motor } \\
\text { activity } \\
\text { Reduction in the } \\
\text { oviposition }\end{array}$ & $\begin{array}{c}\text { Non-toxic in } \\
\text { Vero cell }{ }^{8} \text { at } \\
31.5 \mu \mathrm{M}\end{array}$ & nd & {$[92,103]$} \\
\hline
\end{tabular}


Table 2. Cont.

\begin{tabular}{|c|c|c|c|c|c|c|c|}
\hline \multirow{2}{*}{ Compounds / Substances } & \multirow{2}{*}{ Origin } & \multicolumn{3}{|c|}{ Schistosomicidal activities } & \multicolumn{2}{|c|}{ Assays } & \multirow{2}{*}{ References } \\
\hline & & in vitro & in vivo & Observations & Toxicity & Clinical & \\
\hline Methanol leaves extract & $\begin{array}{l}\text { Baccharis } \\
\text { trimera }\end{array}$ & $\begin{array}{l}\text { S. mansoni- } \\
130 \mu \mathrm{g} / \mathrm{mL}(100 \% \\
\text { mortality in male, } \\
\text { female and } \\
\text { schistosomula }\end{array}$ & nd & $\begin{array}{l}\text { Reduction in the motor } \\
\text { activity } \\
\text { Tegumental alterations }\end{array}$ & $\begin{array}{l}\text { Non-toxic in } \\
\text { human } \\
\text { keratinocytes cell } \\
\text { line at } 250 \mu \mathrm{g} / \mathrm{mL}\end{array}$ & nd & {$[121]$} \\
\hline $\begin{array}{c}\text { Avocado/soybean } \\
\text { unsaponifiables }\end{array}$ & $\begin{array}{c}\text { Persea } \\
\text { americana }\end{array}$ & $\mathrm{Nd}$ & $\begin{array}{l}300 \mathrm{mg} / \mathrm{kg}-3 \text { oral } \\
\text { doses in mice- } 30 \% \\
\text { S. mansoni mortality }\end{array}$ & $\begin{array}{l}\text { Reduction in the motor } \\
\text { activity Tegumental } \\
\text { alterations } \\
\text { Reduction in the } \\
\text { oviposition }\end{array}$ & nd & nd & {$[122]$} \\
\hline Allicin & Allium sativum & $\begin{array}{l}\text { S. mansoni adult- } \\
20 \mathrm{mg} / \mathrm{mL}-\text { no } \\
\text { mortality }\end{array}$ & nd & $\begin{array}{l}5 \mathrm{mg} / \mathrm{mL} \text { tegumental } \\
\text { alterations } \\
10 \mathrm{mg} / \mathrm{mL} \text { changes in } \\
\text { tubercles, loss or } \\
\text { changes in the spines; } \\
15 \text { and } 20 \mathrm{mg} / \mathrm{mL} \\
\text { tegumental disruption } \\
\text { (vesicle and ulceration) }\end{array}$ & nd & nd & {$[123]$} \\
\hline
\end{tabular}

${ }^{1}$ Male CD1 albino—16 injections and total dose of $400 \mathrm{mg} / \mathrm{kg} ;{ }^{2}$ Chinese hamster lung fibroblasts; ${ }^{3}$ Swiss albino; ${ }^{4}$ Male Balb/c — daily doses for 14 days; ${ }^{5}$ Female Balb/c- doses administered at day 0, 20 and 60 post infection; Rats - intramuscular dose; ${ }^{6}$ Rabbits and dogs treated 7, 14, 21, 28, 35 days post infection; ${ }^{7}$ KB-Cell line of human oral carcinoma, P388-murine leukemia , L1210-Mouse lymphocytic leukemia cells; ${ }^{8}$ African green monkey kidney fibroblast. 


\subsubsection{Compounds Acting on the Tegument Structure or Composition}

The tegument in Schistosoma sp. is involved in several vital functions such as nutrient absorption, secretion and by acting as a physical barrier against components of the humoral and cellular host-immune system [124,125]. It is constantly being renewed. Due to these facts and the previous observations that drugs affecting the tegument make the parasites more sensitive to the host immune response, make it a relevant target for drug discovery. Thus, drugs leading to tegument alterations such as vacuolization or observable surface modifications, like peeling, loss of spines or changes in protuberances are considered to be suitable for in in vivo testing (Table 2) [88,120]. However, beside visible modifications of the tegument, additional criteria should be used to evaluate the potential schistosomicidal activity of a drug or extract, since these alterations not always affect the survival of the parasite [123]. Due to the morphological and biochemical differences between male and female parasites, the efficiency of the drug can be gender specific. For example, in in vivo studies with S. mansoni it was observed that at a concentration of $400 \mathrm{mg} / \mathrm{kg}$ curcumine was 10 -fold more active against male than female worms [99,113]. On the other hand, it was reported that artemeter was more active against females of $S$. mansoni $[119,126]$. Compounds targeting Schistosoma sp. in a sex specific manner are effective for treating the infected individuals, improving their clinical outcome and their ability of transmit the disease through the diminution of the released eggs to the environment.

\subsubsection{Compounds Acting on the Parasite Nervous System}

The nervous system of Schistosoma sp., as well as those of other helminthes, has been considered a relevant target for drug discovery. Some observable changes such as parasite motility were associated to interfere with the activity of neurotransmitters or neuromodulators like serotonin, dopamine, acetylcholine, epinephrine, glutamate and a variety of neuropeptides [65,127-130]. In this context, Hillman et al. [131] used a fluorescent analogue of acetylcholine and validated the parasite cholinergic receptors as a drug target for S. mansoni. For these in vitro experiments the worms' motor activity is a main parameter; however, although drugs causing significant motor alterations are usually evaluated as hits, their effect is not always related to the drug action.

\section{Trypanosomatids}

Human pathogens of the genus Leishmania and Trypanosoma are restricted to several species causing Chagas disease (Trypanosoma cruzi), sleeping sickness (T. brucei) and leishmaniosis (a group of disease caused by parasites of the genus Leishmania). The natural transmission of the first two infections is limited to America and Africa, respectively, while the leishmaniosis is distributed around the world's tropical and subtropical belt. Plants have been used in the traditional medicine to treat infections caused by these human pathogens [132-137]. Pathogenic trypanosomatids are digenetic organisms with complex life cycles involving an insect vector and a mammalian host (including humans). To make it more complex-with exception of Trypanosoma brucei-all other pathogenic trypanosomatids have at least one intracellular stage in the mammalian host, which plays a major role in the establishment of the chronic infection and/or in the pathogenesis. Thus, successful therapeutic compounds should be accessible to the respective intracellular compartment in order to target the 
parasite. As mentioned, T. brucei does not have an intracellular cycle in the mammalian host. This fact does not make the challenge easier: in the advanced stages of the disease, the parasites reach the central nervous system (CNS) and as a consequence the successful drug should ideally be able to pass the blood-brain barrier.

As the insect stages of trypanosomatids can be easily cultured in axenic media, most of tests for trypanocidal and leishmanicidal activities have been carried out in these systems. However, the evaluation of compounds on insect stages presents severe limitations due to the fact that the effect cannot be extrapolated to the mammalian stages. Thus, last-generation high throughput screening platforms were developed to evaluate the effect of compounds (particularly those against $T$. cruzi and Leishmania spp.) in mammalian infected cells. Until today, most extracts and plant derived compounds have been evaluated in axenic systems, some of them in in vitro or ex vivo infections systems and only a limited number of them have been evaluated in vivo (Table 3). It is worth mentioning that-with some exceptions - only the mode of action of cubebin and its derivatives has thus far been elucidated [138].

A variety of compounds belonging to the alkaloid family presents trypanocidal activity. Most of them are phenols, therpenoids of quinines. However, none of them can be considered as promising drug candidates yet, due to the limited in vivo data (Table 3). Interestingly, most of these active compounds against Trypanosoma sp. and Leishmania spp. are derived from plant species of the genus Piper (belonging to the family Piperaceae). The variety of the metabolites derived from this species is well documented. Compounds of the primary and secondary metabolism of Piperaceae have been isolated and several of them present a well-documented biological activity within several organisms including S. mansoni as mentioned above [92,103,139-141]. Compounds of the plant families Asteraceae and Lauraceae reveal also activity against trypanosomatids. However, the quantity of these compounds reported up to now, is reduced in comparison to those found in Piperaceae [91,142]. The fact that most of anti-trypanosomatid activities were found in members of a single family suggests that the search for these activities was somehow restricted. As plants can be conceived as "natural organic synthesis laboratories", it is highly emphasized to test and isolate more extracts from plants against trypanosomatids in order to obtain new molecules to fight these neglected diseases. 
Table 3. List of medicinal plants, products and active compounds known to have anti-trypanosomal properties.

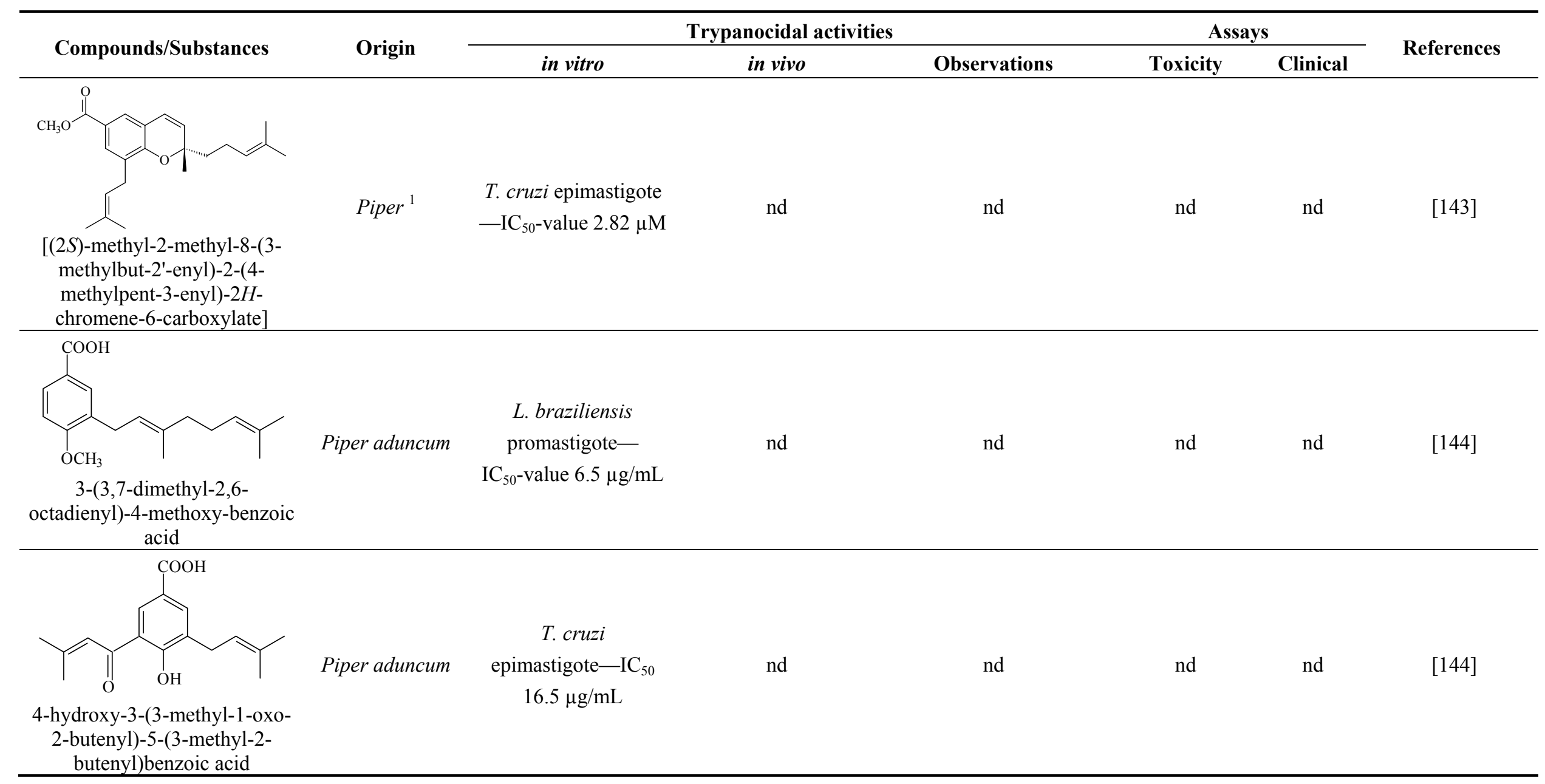


Table 3. Cont

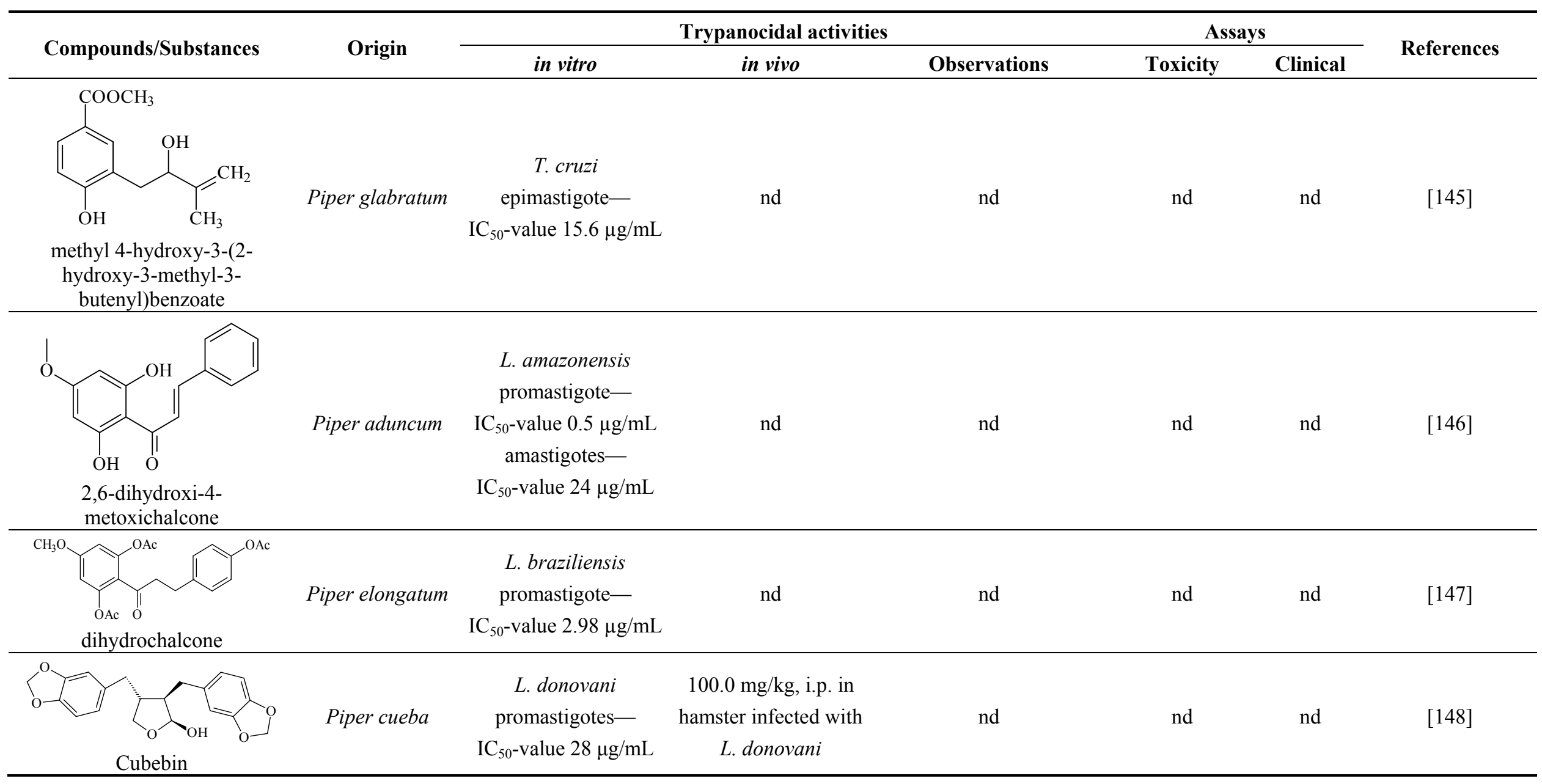


Table 3. Cont.

\begin{tabular}{|c|c|c|c|c|c|c|c|}
\hline \multirow{2}{*}{ Compounds/Substances } & \multirow{2}{*}{ Origin } & \multicolumn{3}{|c|}{ Trypanocidal activities } & \multicolumn{2}{|c|}{ Assays } & \multirow{2}{*}{ References } \\
\hline & & in vitro & in vivo & Observations & Toxicity & Clinical & \\
\hline Conocarpan & Piper regnellii & $\begin{array}{c}T . \text { cruzi } \\
\text { epimastigote- } \\
\mathrm{IC}_{50 \text {-value } 8.0 \mu \mathrm{g} / \mathrm{mL}}\end{array}$ & nd & nd & nd & nd & [149] \\
\hline Eupomatenoid & Piper regnellii & $\begin{array}{c}\text { T. cruzi } \\
\text { epimastigote- } \\
\mathrm{IC}_{50} \text {-value } 7.0 \mu \mathrm{g} / \mathrm{mL}\end{array}$ & nd & nd & $\begin{array}{c}\text { Non-toxic in } \\
\text { Vero cells } \\
\left(\mathrm{CC}_{50}\right. \\
250 \mu \mathrm{g} / \mathrm{mL})\end{array}$ & nd & [149] \\
\hline & $\begin{array}{c}\text { Piper } \\
\text { solmsianum }\end{array}$ & $\begin{array}{c}\text { T. cruzi trypomastigote } \\
-\mathrm{IC}_{50} \text {-value } \\
8.74 \mu \mathrm{g} / \mathrm{mL}\end{array}$ & nd & nd & nd & nd & {$[150]$} \\
\hline Piperine & Piper & $\begin{array}{c}\text { T. cruzi } \\
\text { epimastigote- } \\
\mathrm{IC}_{50} \text {-value } 7.36 \mu \mathrm{M} \\
\text { amastigote- } \\
\mathrm{IC}_{50} \text {-value } 4.91 \mu \mathrm{M}\end{array}$ & nd & nd & nd & nd & {$[151]$} \\
\hline${ }^{\mathrm{H}_{3} \mathrm{C}-\mathrm{O}}$ Piplartine & $\begin{array}{c}\text { Piper } \\
\text { tuberculatum } \\
\text { Piper } \\
\text { retrofractum }\end{array}$ & $\begin{array}{c}\text { T. cruzi } \\
\text { epimastigote- } \\
\mathrm{IC}_{50} \text {-value } 10.5 \mu \mathrm{M} \\
L . \text { donovani } \\
\text { promastigotes- } \\
\mathrm{IC}_{50} \text {-value } 7.5 \mu \mathrm{g} / \mathrm{mL}\end{array}$ & $\begin{array}{c}30 \mathrm{mg} / \mathrm{kg} \text { ip. in } \\
\text { hamster infected with } \\
\text { L. donovani }\end{array}$ & nd & nd & nd & {$[148,152]$} \\
\hline
\end{tabular}


Table 3. Cont.

\begin{tabular}{|c|c|c|c|c|c|c|c|}
\hline \multirow{2}{*}{ Compounds/Substances } & \multirow{2}{*}{ Origin } & \multicolumn{3}{|c|}{ Trypanocidal activities } & \multicolumn{2}{|c|}{ Assays } & \multirow{2}{*}{ Reference } \\
\hline & & in vitro & in vivo & Observations & Toxicity & Clinical & \\
\hline $\begin{array}{l}\text { methyl 3,4-dihydroxy-5-(3'- } \\
\text { methyl-2'-butenyl)benzoate }\end{array}$ & Piper glabratum & $\begin{array}{l}\text { L. braziliensis, } \\
\text { L. amazonensis and } \\
\text { L. donovani- } \\
\mathrm{IC}_{50^{-} \mathrm{value}} \\
13.8-18.5 \mu \mathrm{g} / \mathrm{mL})\end{array}$ & nd & nd & nd & nd & [145] \\
\hline $\begin{array}{l}\text { OH } \\
\text { methyl 3,4-dihydroxy-5-(2- } \\
\text { hydroxy-3- } \\
\text { methylbutenyl)benzoate }\end{array}$ & Piper glabratum & $\begin{array}{l}\text { T cruzi epimestigote- } \\
\text { IC }_{50} \text {-value } 16.4 \mu \mathrm{g} / \mathrm{mL}\end{array}$ & nd & nd & nd & nd & [145] \\
\hline
\end{tabular}


Table 3. Cont.

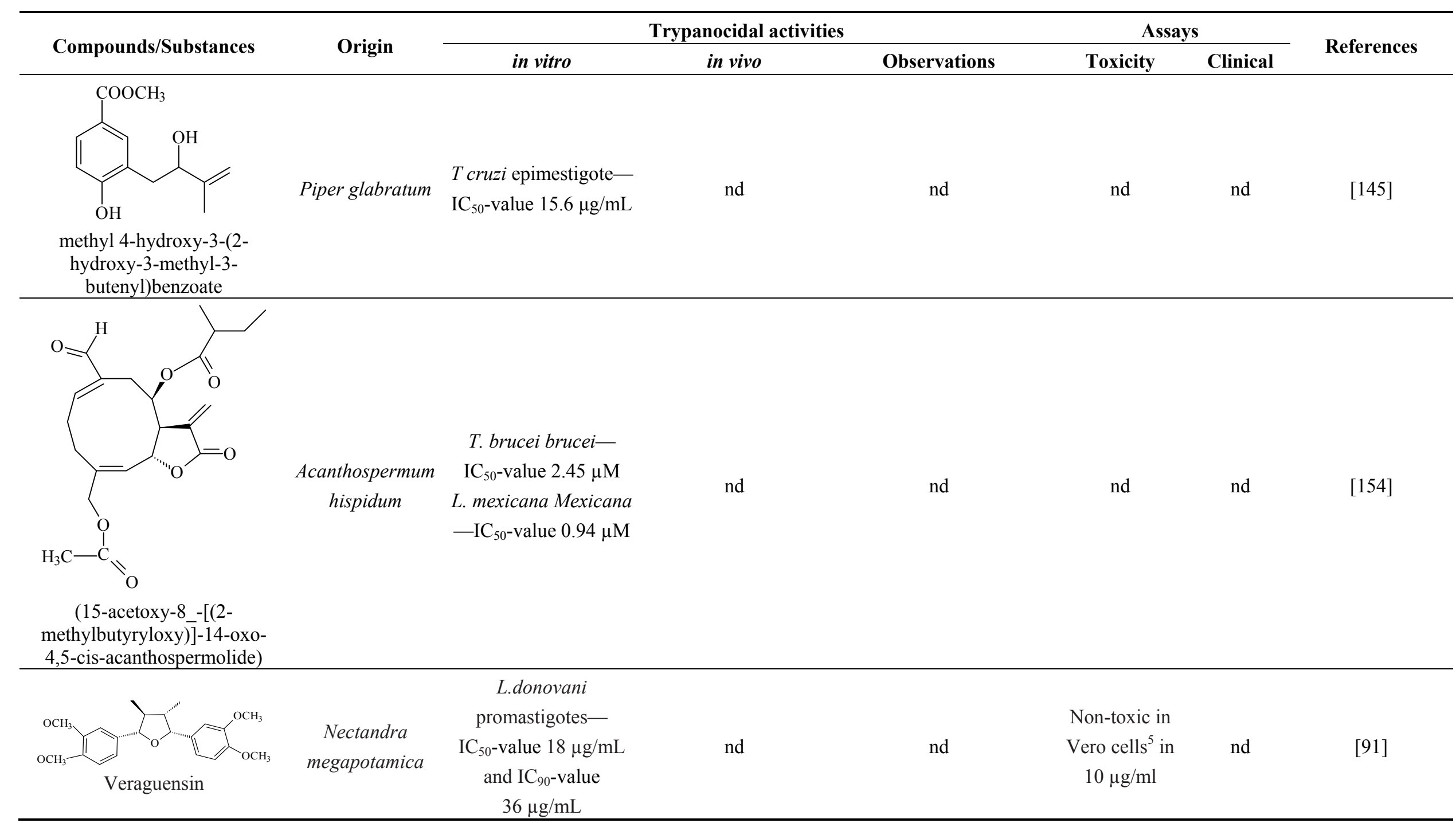


Table 3. Cont.

\begin{tabular}{|c|c|c|c|c|c|c|c|}
\hline \multirow{2}{*}{ Compounds/Substances } & \multirow{2}{*}{ Origin } & \multicolumn{3}{|c|}{ Trypanocidal activities } & \multicolumn{2}{|c|}{ Assays } & \multirow{2}{*}{ References } \\
\hline & & in vitro & in vivo & Observations & Toxicity & Clinical & \\
\hline $\begin{array}{c}\text { Methanol extract from stem } \\
\text { bark }\end{array}$ & Acacia nilotica & na & $\begin{array}{l}200 \mathrm{mg} / \mathrm{kg} \text { body } \\
\text { weight in mice } \\
\text { infected with } \\
\text { T. brucei brucei }\end{array}$ & $\begin{array}{c}\text { Clear the parasites from } \\
\text { circulation } \\
\text { within } 6 \text { days of treatment }\end{array}$ & na & na & {$[136]$} \\
\hline Methanol stem bark extract & $\begin{array}{c}\text { Bombax } \\
\text { buonopozense }\end{array}$ & nd & $\begin{array}{l}300 \mathrm{mg} / \mathrm{kg} \text { body } \\
\text { weight in mice } \\
\text { infected with } \\
\text { T. brucei brucei }\end{array}$ & $\begin{array}{c}\text { Clear the parasites from } \\
\text { circulation within } 7 \text { days } \\
\text { of treatment }\end{array}$ & nd & nd & {$[136]$} \\
\hline Dichloromethane bark extract & $\begin{array}{l}\text { Warburgia } \\
\text { salutaris }\end{array}$ & $\begin{array}{c}\text { T. brucei brucei- } \\
\mathrm{IC}_{50} \text {-value } \\
10.68 \mu \mathrm{g} / \mathrm{mL}\end{array}$ & nd & nd & nd & nd & {$[155]$} \\
\hline 8-epixanthatin $1 \beta, 5 \beta$-epoxide & $\begin{array}{c}\text { Xanthium } \\
\text { brasilicum Vell }\end{array}$ & $\begin{array}{c}\text { T. brucei- } \mathrm{IC}_{50} \\
0.09 \mu \mathrm{g} / \mathrm{mL} \\
\text { T. cruzi- } \mathrm{IC}_{50} \text {-value } \\
2.95 \mu \mathrm{g} / \mathrm{L} \\
\text { L. donovani- } \\
\mathrm{IC}_{50} 0.16 \mu \mathrm{g} / \mathrm{mL}\end{array}$ & nd & nd & nd & nd & [142] \\
\hline
\end{tabular}




\section{Summary}

The most prevalent families revealing anti-filarial activity were Fabaceae represented by five species, followed by four species of Euphrobiaceae and finally Apiaceae, Rosaceae, Annonaceae and Lauraceae which were indicated by two species. The majority of the active compounds isolated from these species revealed an aromatic structure. Among these compounds, gallic, gentisic and ellagic acids were active against $O$. ochengi. Oleanonic, oleanolic acids, gedunin, photogedunin, coumarin and withanolide were interferring with $B$. malayi. It would be important to test these compounds on other filariae to establish a common and effective antifilaricide especially in areas where co-infection occurs.

Among the compounds revealing anti-schistosomal activity, a mode of action has been proposed only for artemisinin and its derivatives. The interference of these drugs with the hemoglobin metabolism is a common feature between Schistosoma and Plasmodium. Both organisms degrade the host hemoglobin into their constituting amino acids, and the free hem is eliminated by the formation of hemozoin, a less reactive iron containing molecule. Free hem is known to be involved in the generation of a variety of different reactive oxygen species and thereby causing oxidative stress. It was proposed that the hem reacts with artemisinin which affects the proliferation of the parasite $[117,156]$.

In general, little is known about the mode of action of natural compounds leading to anti-schistosomal as well as anti trypanosomal activities. More information on the molecular mechanism involved in the action of natural compounds is necessary to predict side effects and analyze the probability of the emergence of resistant strains.

Presently, the set-up of high throughput screening facilities allows a more efficient and rapid identification of interesting schistosomicidal compounds. In this sense, previous studies on the characterization and inhibition of relevant parasite proteins like acetylcholinesterase [67,157], cysteine protease [158] serine protease [159] and glutamatergic receptors in adult S. mansoni [160] are relevant to the development of new possible methods towards the identification and validation of new targets. For example, Abdulla et al. [158] described the viability of applying a medium-throughput phenotypic screening of adult worms and schistosomula in vitro with a library of known drugs to identify putative schistosomicidal drugs. Interestingly, this screening could also be used to investigate the schistosomidal activity of plant derived extracts, products and active compounds.

\section{Acknowledgements}

The authors would like to thank the Fundação de Amparo à Pesquisa do Estado de São Paulo (FAPESP, grants 2011/50631-1 to A.M.S. and 2009/54325-2 to C.W.), the Instituto Nacional de Biologia Estrutural e Química Medicinal em Doenças Infecciosas (INBEQMeDI) and the Conselho Nacional de Desenvolvimento Científico e Tecnológico (CNPq, grant 470272/2011-2 to A.M.S.) as well as the Deutsche Forschungsgemeinschaft (DFG, grant LI 793/5-1 to E.L.) within the framework of the Cameroonian-German Cooperation Project (cameroon.uni-muenster.de) for financial support. D.N. is a fellow of the Alexander von Humboldt Foundation. 


\section{References}

1. Schmidt, T.J.; Khalid, S.A.; Romanha, A.J.; Alves, T.M.; Biavatti, M.W.; Brun, R.; Da Costa, F.B.; de Castro, S.L.; Ferreira, V.F.; de Lacerda, M.V.; et al. The potential of secondary metabolites from plants as drugs or leads against protozoan neglected diseases-Part II. Curr. Med. Chem. 2012, 19, 2176-2228.

2. Schmidt, T.J.; Khalid, S.A.; Romanha, A.J.; Alves, T.M.; Biavatti, M.W.; Brun, R.; Da Costa, F.B.; de Castro, S.L.; Ferreira, V.F.; de Lacerda, M.V.; et al. The potential of secondary metabolites from plants as drugs or leads against protozoan neglected diseases-Part I. Curr. Med. Chem. 2012, 19, 2128-2175.

3. Christen, P.C. Muriel plants as a source of therapeutic and health products. CHIMIA Int. J. Chem. 2012, 66, 320-323.

4. Ioset, J.R. Natural products for neglected diseases: A review. Curr. Organ. Chem. 2008, 12, 643-666.

5. Cavalier-Smith, T. A revised six-kingdom system of life. Biol. Rev. Camb. Philos. Soc. 1998, 73, 203-266.

6. Lambshead, P.J.D. Recent developments in marine benthic biodiversity research. Oceanis 1993, 19, 5-24.

7. Hugot, J.P.; Baujard, P.; Morand, S. Biodiversity in helminths and nematodes as a field of study: An overview. Nematology 2001, 3, 199-208.

8. World Health Organization. Onchocerciasis and Its Control; Report of 512 a WHO Expert Committee on Onchocerciasis Control. Geneva; WHO Technical 513 Report Series; WHO: Geneva, Switzerland, 1995; pp. 1-104.

9. Osei-Atweneboana, M.Y.; Eng, J.K.; Boakye, D.A.; Gyapong, J.O.; Prichard, R.K. Prevalence and intensity of Onchocerca volvulus infection and efficacy of ivermectin in endemic communities in Ghana: A two-phase epidemiological study. Lancet 2007, 369, 2021-2029.

10. Wagman, R.J.E. The New Complete Medical and Health Encyclopedia; Lexicon Publication Inc.: New York, NY, USA, 1982; Volume 4, p. 1310.

11. Navaratnam, V. Recent Advances in the Chemotheraphy of Lymphatic Filariasis. In Proceeding of 34th SEAMEO TROPMED Regional Seminar: Current Status of Filariasis in Southeast Asia, Kuala Lumpur, Malaysia, 26-27 June 1992.

12. World Health Organization. Global programme to eliminate lymphatic filariasis. Wkly. Epidemiol. Rec. 2009, 437-444.

13. Gyapong, J.O.; Kumaraswami, V.; Biswas, G.; Ottesen, E.A. Treatment strategies underpinning the global programme to eliminate lymphatic filariasis. Expert Opin. Pharmacother. 2005, 6, 179-200.

14. Bockarie, M.J.; Taylor, M.J.; Gyapong, J.O. Current practices in the management of lymphatic filariasis. Expert Rev. Anti-Infect. Ther. 2009, 7, 595-605.

15. Liang, J.L.; King, J.D.; Ichimori, K.; Handzel, T.; Pa'au, M.; Lammie, P.J. Impact of five annual rounds of mass drug administration with diethylcarbamazine and albendazole on Wuchereria bancrofti infection in American Samoa. Am. J. Trop. Med. Hyg. 2008, 78, 924-928. 
16. The Carter Center. Available online: http://www.cartercenter.org/health/lf/index.html (accessed on 29 December 2012).

17. The Center of Disease Control and Prevention. Available online: http://www.cartercenter.org/ health/lf/index.html (accessed on 29 December 2012).

18. Winnen, M.; Plaisier, A.P.; Alley, E.S.; Nagelkerke, N.J.; van Oortmarssen, G.; Boatin, B.A.; Habbema, J.D. Can ivermectin mass treatments eliminate onchocerciasis in Africa? Bull World Health Organ. 2002, 80, 384-391.

19. Kaplan, R.M. Drug resistance in nematodes of veterinary importance: A status report. Trends Parasitol. 2004, 20, 477-481.

20. Howell, S.B.; Burke, J.M.; Miller, J.E.; Terrill, T.H.; Valencia, E.; Williams, M.J.; Williamson, L.H.; Zajac, A.M.; Kaplan, R.M. Prevalence of anthelmintic resistance on sheep and goat farms in the southeastern United States. J. Am. Vet. Med. Assoc. 2008, 233, 1913-1919.

21. Moussala, M.; Fobi, G.; Zogo, O.; Hiag, B.L.A.; Bengono, G.; McMoli, T.E. Survenue d'hémorragies rétiniennes lors du traitement de l'onchocercose par l'invermectine chez une patiente co-infectée par la loase. J. Français d'Ophtalmologie 2004, 27, 63-66.

22. Melo, A.C.F.L.; Reis, I.F.; Bevilaqua, C.M.L.; Vieira, L.S.; Echevarria, F.M.; Melo, L.M. Nematodeos resistentes a anti-helminticos em rebanhos de ovinos ecaprinos do estado do Ceará, Brasil. Ciencia Rural 2003, 33, 339-344.

23. Sullivan, K.; Shealy, C.N. Complete Natural Home Remedies; Element Books Limited: Shafterburg, UK, 1997.

24. Robinson, M.M.; Zhang, X. Traditional Medicines: Global Situation, Issues and Challenges; WHO: Geneva, Switzerland, 2011.

25. Achukwi, M.D.; Harnett, W.; Renz, A. Onchocerca ochengi transmission dynamics and the correlation of $O$. ochengi microfilaria density in cattle with the transmission potential. Vet. Res. 2000, 31, 611-621.

26. Nyasse, B.; Ngantchou, I.; Nono, J.J.; Schneider, B. Antifilarial activity in vitro of polycarpol and 3-O-acetyl aleuritolic acid from cameroonian medicinal plants against Onchocerca gutturosa. Nat. Prod. Res. 2006, 20, 391-397.

27. Cho-Ngwa, F.; Abongwa, M.; Ngemenya, M.N.; Nyongbela, K.D. Selective activity of extracts of Margaritaria discoidea and Homalium africanum on Onchocerca ochengi. BMC Complement. Altern. Med. 2010, 10, 62.

28. Ndjonka, D.; Agyare, C.; Luersen, K.; Djafsia, B.; Achukwi, D.; Nukenine, E.N.; Hensel, A.; Liebau, E. In vitro activity of Cameroonian and Ghanaian medicinal plants on parasitic (Onchocerca ochengi) and free-living (Caenorhabditis elegans) nematodes. J. Helminthol. 2011, $85,304-312$.

29. Ndjonka, D.; Ajonina-Ekoti, I.; Djafsia, B.; Luersen, K.; Abladam, E.; Liebau, E. Anogeissus leiocarpus extract on the parasite nematode Onchocerca ochengi and on drug resistant mutant strains of the free-living nematode Caenorhabditis elegans. Vet. Parasitol. 2012, 190, 136-142.

30. Smith, R.A.; Pontiggia, L.; Waterman, C.; Lichtenwalner, M.; Wasserman, J. Comparison of motility, recovery, and methyl-thiazolyl-tetrazolium reduction assays for use in screening plant products for anthelmintic activity. Parasitol. Res. 2009, 105, 1339-1343. 
31. Hoste, H.; Brunet, S.; Paolini, V.; Bahuaud, D.; Chauveau, S.; Fouraste, I.; Lefrileux, Y. Compared in vitro anthelmintic effects of eight tannin-rich plants browsed by goats in the southern part of France. Option Méditerrenéennes 2009, 431-436.

32. Thomsen, H.; Reider, K.; Franke, K.; Wessjohann, L.A.; Keiser, J.; Dagne, E.; Arnold, N. Characterization of constituents and anthelmintic properties of Hagenia abyssinica. Sci. Pharm. 2012, 80, 433-446.

33. Katiki, L.M.; Ferreira, J.F.; Gonzalez, J.M.; Zajac, A.M.; Lindsay, D.S.; Chagas, A.C.; Amarante, A.F. Anthelmintic effect of plant extracts containing condensed and hydrolyzable tannins on Caenorhabditis elegans, and their antioxidant capacity. Vet. Parasitol. 2012, 18, $218-227$.

34. Lakshmi, V.; Kumar, R.; Gupta, P.; Varshney, V.; Srivastava, M.N.; Dikshit, M.; Murthy, P.K.; Misra-Bhattacharya, S. The antifilarial activity of a marine red alga, Botryocladia leptopoda, against experimental infections with animal and human filariae. Parasitol. Res. 2004, 93, 468-474.

35. Fujimaki, Y.; Kamachi, T.; Yanagi, T.; Caceres, A.; Maki, J.; Aoki, Y. Macrofilaricidal and microfilaricidal effects of Neurolaena lobata, a Guatemalan medicinal plant, on Brugia pahangi. J. Helminthol. 2005, 79, 23-28.

36. Misra, N.; Sharma, M.; Raj, K.; Dangi, A.; Srivastava, S.; Misra-Bhattacharya, S. Chemical constituents and antifilarial activity of Lantana camara against human lymphatic filariid Brugia malayi and rodent filariid Acanthocheilonema viteae maintained in rodent hosts. Parasitol. Res. 2007, 100, 439-448.

37. Sahare, K.N.; Anandhraman, V.; Meshram, V.G.; Meshram, S.U.; Reddy, M.V.; Tumane, P.M.; Goswami, K. Anti-microfilarial activity of methanolic extract of Vitex negundo and Aegle marmelos and their phytochemical analysis. Indian J. Exp. Biol. 2008, 46, 128-131.

38. Sharma, R.D.; Veerpathran, A.R.; Dakshinamoorthy, G.; Sahare, K.N.; Goswami, K.; Reddy, M.V. Possible implication of oxidative stress in anti filarial effect of certain traditionally used medicinal plants in vitro against Brugia malayi microfilariae. Pharmacogn. Res. 2010, 2, $350-354$.

39. Gaur, R.L.; Sahoo, M.K.; Dixit, S.; Fatma, N.; Rastogi, S.; Kulshreshtha, D.K.; Chatterjee, R.K.; Murthy, P.K. Antifilarial activity of Caesalpinia bonducella against experimental filarial infections. Indian J. Med. Res. 2008, 128, 65-70.

40. Mathew, N.; Misra-Bhattacharya, S.; Perumal, V.; Muthuswamy, K. Antifilarial lead molecules isolated from Trachyspermum ammi. Molecules 2008, 13, 2156-2168.

41. Singh, M.; Shakya, S.; Soni, V.K.; Dangi, A.; Kumar, N.; Bhattacharya, S.M. The n-hexane and chloroform fractions of Piper betle L. trigger different arms of immune responses in BALB/c mice and exhibit antifilarial activity against human lymphatic filarid Brugia malayi. Int. Immunopharmacol. 2009, 9, 716-728.

42. Misra, S.; Verma, M.; Mishra, S.K.; Srivastava, S.; Lakshmi, V.; Misra-Bhattacharya, S. Gedunin and photogedunin of Xylocarpus granatum possess antifilarial activity against human lymphatic filarial parasite Brugia malayi in experimental rodent host. Parasitol. Res. 2011, 109, 1351-1360. 
43. Zaridah, M.Z.; Idid, S.Z.; Omar, A.W.; Khozirah, S. In vitro antifilarial effects of three plant species against adult worms of subperiodic Brugia malayi. J. Ethnopharmacol. 2001, 78, 79-84.

44. Sashidhara, K.V.; Singh, S.P.; Misra, S.; Gupta, J.; Misra-Bhattacharya, S. Galactolipids from Bauhinia racemosa as a new class of antifilarial agents against human lymphatic filarial parasite, Brugia malayi. Eur. J. Med. Chem. 2012, 50, 230-235.

45. Azeez, S.; Babu, R.O.; Aykkal, R.; Narayanan, R. Virtual screening and in vitro assay of potential drug like inhibitors from spices against glutathione-S-transferase of filarial nematodes. J. Mol. Model. 2012, 18, 151-163.

46. Kushwaha, S.; Roy, S.; Maity, R.; Mallick, A.; Soni, V.K.; Singh, P.K.; Chaurasiya, N.D.; Sangwan, R.S.; Misra-Bhattacharya, S.; Mandal, C. Chemotypical variations in Withania somnifera lead to differentially modulated immune response in BALB/c mice. Vaccine 2012, 30, 1083-1093.

47. Kushwaha, S.; Soni, V.K.; Singh, P.K.; Bano, N.; Kumar, A.; Sangwan, R.S.; Misra-Bhattacharya, S. Withania somnifera chemotypes NMITLI 101R, NMITLI 118R, NMITLI 128R and withaferin A protect Mastomys coucha from Brugia malayi infection. Parasite Immunol. 2012, 34, 199-209.

48. Salem, M.L. Immunomodulatory and therapeutic properties of the Nigella sativa L. seed. Int. Immunopharmacol. 2005, 5, 1749-1770.

49. Hoerauf, A.; Mand, S.; Fischer, K.; Kruppa, T.; Marfo-Debrekyei, Y.; Debrah, A.Y.; Pfarr, K.M.; Adjei, O.; Buttner, D.W. Doxycycline as a novel strategy against bancroftian filariasis-depletion of Wolbachia endosymbionts from Wuchereria bancrofti and stop of microfilaria production. Med. Microbiol. Immunol. 2003, 192, 211-216.

50. Taylor, M.J.; Makunde, W.H.; McGarry, H.F.; Turner, J.D.; Mand, S.; Hoerauf, A. Macrofilaricidal activity after doxycycline treatment of Wuchereria bancrofti: A double-blind, randomised placebo-controlled trial. Lancet 2005, 365, 2116-2121.

51. Sahare, K.N.; Anandharaman, V.; Meshram, V.G.; Meshram, S.U.; Gajalakshmi, D.; Goswami, K.; Reddy, M.V. In vitro effect of four herbal plants on the motility of Brugia malayi microfilariae. Indian J. Med. Res. 2008, 127, 467-471.

52. World Health Organization. Schistosomiasis: Population requiring preventive chemotherapy and number of people treated in 2010. Wkly Epidemiol. Rec. 2012, 4, 37-44.

53. King, C.H. Parasites and poverty: The case of schistosomiasis. Acta Trop 2010, 113, 95-104.

54. Gray, D.J.; McManus, D.P.; Li, Y.; Williams, G.M.; Bergquist, R.; Ross, A.G. Schistosomiasis elimination: Lessons from the past guide the future. Lancet Infect. Dis. 2010, 10, 733-736.

55. Siddiqui, A.A.; Siddiqui, B.A.; Ganley-Leal, L. Schistosomiasis vaccines. Hum. Vaccin. 2011, 7 , 1192-1197.

56. Gryseels, B.; Polman, K.; Clerinx, J.; Kestens, L. Human schistosomiasis. Lancet 2006, 368, 1106-1118.

57. Rollinson, D.; Knopp, S.; Levitz, S.; Stothard, J.R.; Tchuente, L.A.; Garba, A.; Mohammed, K.A.; Schur, N.; Person, B.; Colley, D.G.; et al. Time to set the agenda for schistosomiasis elimination. Acta Trop. 2012, in press.

58. Fenwick, A.W., J.P. Schistosomiasis: Challenges for control, treatment and drug resistance. Curr. Opin. Infect. Dis. 2006, 19, 577-582. 
59. Steinmann, P.; Keiser, J.; Bos, R.; Tanner, M.; Utzinger, J. Schistosomiasis and water resources development: Systematic review, meta-analysis, and estimates of people at risk. Lancet Infect. Dis. 2006, 6, 411-425.

60. Fenwick, A.; Savioli, L. Schistosomiasis elimination. Lancet Infect. Dis. 2011, 11, 346-347.

61. Rapado, L.N.; Nakano, E.; Ohlweiler, F.P.; Kato, M.J.; Yamaguchi, L.F.; Pereira, C.A.; Kawano, T. Molluscicidal and ovicidal activities of plant extracts of the Piperaceae on Biomphalaria glabrata (Say, 1818). J. Helminthol. 2011, 85, 66-72.

62. Chimbari, M.J. Enhancing schistosomiasis control strategy for zimbabwe: Building on past experiences. J. Parasitol. Res. 2012, 2012, doi:10.1155/2012/353768.

63. World Health Organization. Working to Overcome the Global Impact of Neglected Tropical Diseases-First WHO Report on Neglected Tropical Diseases; WHO Press: Geneva, Switzerland, 2010; p. 184.

64. Bueding, E.; Fisher, J. Factors affecting the inhibition of phosphofructokinase activity of Schistosoma mansoni by trivalent organic antimonials. Biochem. Pharmacol. 1966, 15, 1197-1211.

65. Cioli, D.; Pica-Mattoccia, L.; Archer, S. Antischistosomal drugs: Past, present and future? Pharmacol. Ther. 1995, 68, 35-85.

66. Denham DA, H.R. The effect of metrifonate in vitro on Schistosoma haematobium and S. mansoni adults. Trans. R. Soc. Trop. Med. Hyg. 1971, 65, 695-696.

67. Holmstedt, B.; Nordgren, I.; Sandoz, M.; Sundwall, A. Metrifonate. Summary of toxicological and pharmacological information available. Arch. Toxicol. 1978, 41, 3-29.

68. Cioli, D. Chemotherapy of schistosomiasis: An update. Parasitol. Today 1998, 14, 418-422.

69. Pica-Mattoccia, L.; Cioli, D. Studies on the mode of action of oxamniquine and related schistosomicidal drugs. Am. J. Trop. Med. Hyg. 1985, 34, 112-118.

70. Kohn, A.B.; Anderson, P.A.; Roberts-Misterly, J.M.; Greenberg, R.M. Schistosome calcium channel beta subunits. Unusual modulatory effects and potential role in the action of the antischistosomal drug praziquantel. J. Biol. Chem. 2001, 276, 36873-36876.

71. Jeziorski, M.C.; Greenberg, R.M. Voltage-gated calcium channel subunits from platyhelminths: Potential role in praziquantel action. Int. J. Parasitol. 2006, 36, 625-632.

72. Salvador-Recatala, V.; Greenberg, R.M. Calcium channels of schistosomes: Unresolved questions and unexpected answers. Wiley Interdiscip. Rev. 2012, 1, 85-93.

73. Day, T.A.B.J.; Pax, R.A. Praziquantel: The enigmatic antiparasitic. Parasitol. Today 1992, 8, 342-344.

74. Utzinger, J.; Keiser, J.; Shuhua, X.; Tanner, M.; Singer, B.H. Combination chemotherapy of schistosomiasis in laboratory studies and clinical trials. Antimicrob. Agents Chemother. 2003, 47, 1487-1495.

75. Sabah, A.A.; Fletcher, C.; Webbe, G.; Doenhoff, M.J. Schistosoma mansoni: Chemotherapy of infections of different ages. Exp. Parasitol. 1986, 61, 294-303.

76. Fenwick, A.; Savioli, L.; Engels, D.; Robert Bergquist, N.; Todd, M.H. Drugs for the control of parasitic diseases: Current status and development in schistosomiasis. Trends Parasitol. 2003, $19,509-515$. 
77. Doenhoff, M.J.; Hagan, P.; Cioli, D.; Southgate, V.; Pica-Mattoccia, L.; Botros, S.; Coles, G.; Tchuem Tchuente, L.A.; Mbaye, A.; Engels, D. Praziquantel: Its use in control of schistosomiasis in sub-Saharan Africa and current research needs. Parasitology 2009, 136, 1825-1835.

78. Utzinger, J.; N'Goran E, K.; Caffrey, C.R.; Keiser, J. From innovation to application: Social-ecological context, diagnostics, drugs and integrated control of schistosomiasis. Acta Trop. 2011, 120, S121-S137.

79. Bennett, J.L.; Day, T.; Liang, F.T.; Ismail, M.; Farghaly, A. The development of resistance to anthelmintics: A perspective with an emphasis on the antischistosomal drug praziquantel. Exp. Parasitol. 1997, 87, 260-267.

80. Kusel, J.; Hagan, P. Praziquantel—its use, cost and possible development of resistance. Parasitol. Today 1999, 15, 352-354.

81. Ismail, M.; Botros, S.; Metwally, A.; William, S.; Farghally, A.; Tao, L.F.; Day, T.A.; Bennett, J.L. Resistance to praziquantel: Direct evidence from Schistosoma mansoni isolated from Egyptian villagers. Am. J. Trop. Med. Hyg. 1999, 60, 932-935.

82. Cioli, D. Praziquantel: Is there real resistance and are there alternatives? Curr. Opin. Infect. Dis. 2000, 13, 659-663.

83. Doenhoff, M.J.; Kusel, J.R.; Coles, G.C.; Cioli, D. Resistance of Schistosoma mansoni to praziquantel: Is there a problem? Trans. R. Soc. Trop. Med. Hyg. 2002, 96, 465-469.

84. Doenhoff, M.; Kimani, G.; Cioli, D. Praziquantel and the control of schistosomiasis. Parasitol. Today 2000, 16, 364-366.

85. Gryseels, B.; Mbaye, A.; de Vlas, S.J.; Stelma, F.F.; Guisse, F.; van Lieshout, L.; Faye, D.; Diop, M.; Ly, A.; Tchuem-Tchuente, L.A.; et al. Are poor responses to praziquantel for the treatment of Schistosoma mansoni infections in Senegal due to resistance? An overview of the evidence. Trop. Med. Int. Health 2001, 6, 864-873.

86. Caffrey, C.R. Chemotherapy of schistosomiasis: Present and future. Curr. Opin. Chem. Biol. 2007, 11, 433-439.

87. Sabra, A.N.; Botros, S.S. Response of Schistosoma mansoni isolates having different drug sensitivity to praziquantel over several life cycle passages with and without therapeutic pressure. J. Parasitol. 2008, 94, 537-541.

88. Doenhoff, M.J.; Cioli, D.; Utzinger, J. Praziquantel: Mechanisms of action, resistance and new derivatives for schistosomiasis. Curr. Opin. Infect. Dis. 2008, 21, 659-667.

89. Barakat, R.; El Morshedy, H. Efficacy of two praziquantel treatments among primary school children in an area of high Schistosoma mansoni endemicity, Nile Delta, Egypt. Parasitology 2011, 138, 440-446.

90. Kayser, O.; Kiderlen, A.F.; Croft, S.L. Natural products as antiparasitic drugs. Parasitol. Res. 2003, 90, S55-S62.

91. Da Silva Filho, A.A.; Costa, E.S.; Cunha, W.R.; Silva, M.L.; Nanayakkara, N.P.; Bastos, J.K. In vitro antileishmanial and antimalarial activities of tetrahydrofuran lignans isolated from Nectandra megapotamica (Lauraceae). Phytother. Res. 2008, 22, 1307-1310.

92. Moraes, J.; Nascimento, C.; Lopes, P.O.; Nakano, E.; Yamaguchi, L.F.; Kato, M.J.; Kawano, T. Schistosoma mansoni: In vitro schistosomicidal activity of piplartine. Exp. Parasitol. 2011, 127, 357-364. 
93. Ndamba, J.; Chidimu, M.G.; Zimba, M.; Gomo, E.; Munjoma, M. An investigation of the schistosomiasis transmission status in Harare. Cent. Afr. J. Med. 1994, 40, 337-342.

94. Clark, T.E.; Appleton, C.C.; Kvalsvig, J.D. Schistosomiasis and the use of indigenous plant molluscicides: A rural South African perspective. Acta Trop. 1997, 66, 93-107.

95. Sparg, S.G.; van Staden, J.; Jager, A.K. Efficiency of traditionally used South African plants against schistosomiasis. J. Ethnopharmacol. 2000, 73, 209-214.

96. Molgaard, P.; Nielsen, S.B.; Rasmussen, D.E.; Drummond, R.B.; Makaza, N.; Andreassen, J. Anthelmintic screening of Zimbabwean plants traditionally used against schistosomiasis. J. Ethnopharmacol. 2001, 74, 257-264.

97. Bah, S.; Diallo, D.; Dembele, S.; Paulsen, B.S. Ethnopharmacological survey of plants used for the treatment of schistosomiasis in Niono District, Mali. J. Ethnopharmacol. 2006, 105, 387-399.

98. Cunha, N.L.U.C.; Cintra, L.S.; Souza, H.C.; Peixoto, J.A.; Silva, C.P.; Magalhães, L.G.; Groppo, M.; Rodrigues, V.; Filho, A.A.S.; Silva, M.L.A.; et al. In Vitro schistosomicidal activity of some brazilian cerrado species and their isolated compounds. Evidence-Based Complement. Alter. Med. 2012, 2012, doi:10.1155/2012/173614.

99. Magalhaes, L.G.; Machado, C.B.; Morais, E.R.; Moreira, E.B.; Soares, C.S.; da Silva, S.H.; da Silva Filho, A.A.; Rodrigues, V. In vitro schistosomicidal activity of curcumin against Schistosoma mansoni adult worms. Parasitol. Res. 2009, 104, 1197-1201.

100. Magalhaes, L.G.; Kapadia, G.J.; da Silva Tonuci, L.R.; Caixeta, S.C.; Parreira, N.A.; Rodrigues, V.; da Silva Filho, A.A. In vitro schistosomicidal effects of some phloroglucinol derivatives from Dryopteris species against Schistosoma mansoni adult worms. Parasitol. Res. 2010, 106, 395-401.

101. Caixeta, S.C.; Melo, N.I.; Wakabayashi, K.A.L.; Aguiar, G.P.; Aguiar, D.P.; Mantovani, A.L.L.; Alves, J.M.; Oliveira, P.F.; Tavares, D.C.; Groppo, M.G.; et al. Chemical composition and in vitro schistosomicidal activity of the essential oil of Plectranthus neochilus grown in southeast Brazil. Chem. Biodivers. 2011, 8, 2147-2157.

102. Pereira, A.C.; Magalhaes, L.G.; Goncalves, U.O.; Luz, P.P.; Moraes, A.C.; Rodrigues, V.; da Matta Guedes, P.M.; da Silva Filho, A.A.; Cunha, W.R.; Bastos, J.K.; et al. Schistosomicidal and trypanocidal structure-activity relationships for (+/-)-licarin A and its (-)- and (+)-enantiomers. Phytochemistry 2011, 72, 1424-1430.

103. Moraes, J.; Nascimento, C.; Yamaguchi, L.F.; Kato, M.J.; Nakano, E. Schistosoma mansoni: In vitro schistosomicidal activity and tegumental alterations induced by piplartine on schistosomula. Exp. Parasitol. 2012, 132, 222-227.

104. Jisaka, M.; Kawanaka, M.; Sugiyama, H.; Takegawa, K.; Huffman, M.A.; Ohigashi, H.; Koshimizu, K. Antischistosomal activities of sesquiterpene lactones and steroid glucosides from Vernonia amygdalina, possibly used by wild chimpanzees against parasite-related diseases. Biosci. Biotechnol. Biochem. 1992, 56, 845-846.

105. McIntosh, H.M.; Olliaro, P. Artemisinin derivatives for treating uncomplicated malaria. Cochrane Database Syst. Rev. 2000, CD000256. 
106. Le, W.J.; You, J.Q.; Yang, Y.Q.; Mei, J.Y.; Guo, H.F.; Yang, H.Z.; Zhang, C.W. Studies on the efficacy of artemether in experimental schistosomiasis (author's transl). Yao Xue Xue Bao 1982, 17, 187-193.

107. Yue, W.J.; You, J.Q.; Mei, J.Y. Effects of artemether on Schistosoma japonicum adult worms and ova. Zhongguo Yao Li Xue Bao 1984, 5, 60-63.

108. Utzinger, J.; Xiao, S.; N'Goran, E.K.; Bergquist, R.; Tanner, M. The potential of artemether for the control of schistosomiasis. Int. J. Parasitol. 2001, 31, 1549-1562.

109. Araujo, N.; Kohn, A.; Katz, N. Activity of the artemether in experimental schistosomiasis mansoni. Mem. Inst. Oswaldo Cruz 1991, 86, 185-188.

110. Utzinger, J.; N'Goran, E.K.; N’Dri, A.; Lengeler, C.; Xiao, S.; Tanner, M. Oral artemether for prevention of Schistosoma mansoni infection: Randomised controlled trial. Lancet 2000, 355, 1320-1325.

111. Keiser, J.; Chollet, J.; Xiao, S.H.; Mei, J.Y.; Jiao, P.Y.; Utzinger, J.; Tanner, M. Mefloquine-An aminoalcohol with promising antischistosomal properties in mice. PLoS Negl. Trop. Dis. 2009, 3, e350.

112. Erasmus, D.A. A comparative study of the reproductive system of mature, immature and "unisexual" female Schistosoma mansoni. Parasitology 1973, 67, 165-183.

113. Allam, G. Immunomodulatory effects of curcumin treatment on murine schistosomiasis mansoni. Immunobiology 2009, 214, 712-727.

114. Cichewicz, R.H.L.; McKerrow, JH; Nair, MG. Kwanzoquinones A-G and other constituents of Hemerocallis fulva "Kwanzo" roots and their activity against the human pathogenic trematode Schistosoma mansoni. Tetrahedron 2002, 58, 8597-8606.

115. El-Shenawy, N.S.; Soliman, M.F.; Abdel-Nabi, I.M. Does Cleome droserifolia have anti-schistosomiasis mansoni activity? Rev. Inst. Med. Trop. Sao Paulo 2006, 48, 223-228.

116. Jatsa, H.B.; Ngo Sock, E.T.; Tchuem Tchuente, L.A.; Kamtchouing, P. Evaluation of the in vivo activity of different concentrations of Clerodendrum umbellatum Poir against Schistosoma mansoni infection in mice. Afr. J. Tradit. Complement. Altern. Med. 2009, 6, 216-221.

117. Jiraungkoorskul, W.; Sahaphong, S.; Sobhon, P.; Riengrojpitak, S.; Kangwanrangsan, N. Schistosoma mekongi: The in vitro effect of praziquantel and artesunate on the adult fluke. Exp. Parasitol. 2006, 113, 16-23.

118. Utzinger, J.; Chollet, J.; Tu, Z.; Xiao, S.; Tanner, M. Comparative study of the effects of artemether and artesunate on juvenile and adult Schistosoma mansoni in experimentally infected mice. Trans. R. Soc. Trop. Med. Hyg. 2002, 96, 318-323.

119. Lescano, S.Z.; Chieffi, P.P.; Canhassi, R.R.; Boulos, M.; Amato Neto, V. Antischistosomal activity of artemether in experimental Schistosomiasis mansoni. Rev. Saude Publica 2004, 38, 71-75.

120. Xiao, S.; Shen, B.; Chollet, J.; Utzinger, J.; Tanner, M. Tegumental changes in adult Schistosoma mansoni harbored in mice treated with artemether. J. Parasitol. 2000, 86, 1125-1132.

121. De Oliveira, C.B.; Comunello, L.N.; Lunardelli, A.; Amaral, R.H.; Pires, M.G.; da Silva, G.L.; Manfredini, V.; Vargas, C.R.; Gnoatto, S.C.; de Oliveira, J.R.; Gosmann, G. Phenolic enriched 
extract of Baccharis trimera presents anti-inflammatory and antioxidant activities. Molecules 2012, 17, 1113-1123.

122. Soliman, M.F. Evaluation of avocado/soybean unsaponifiable alone or concurrently with praziquantel in murine schistosomiasis. Acta Trop. 2012, 122, 261-266.

123. Lima, C.M.; Freitas, F.I.; Morais, L.C.; Cavalcanti, M.G.; Silva, L.F.; Padilha, R.J.; Barbosa, C.G.; Santos, F.A.; Alves, L.C.; Diniz Mde, F. Ultrastructural study on the morphological changes to male worms of Schistosoma mansoni after in vitro exposure to allicin. Rev. Soc. Bras. Med. Trop. 2011, 44, 327-330.

124. Race, G.J.; Martin, J.H.; Moore, D.V.; Larsh, J.E., Jr. Scanning and transmission electronmicroscopy of Schistosoma mansoni eggs, cercariae, and adults. Am. J. Trop. Med. Hyg. 1971, 20, 914-924.

125. Hockley, D.J. Ultrastructure of the tegument of Schistosoma. Adv Parasitol 1973, 11, 233-305.

126. Mitsui, Y.; Miura, M.; Aoki, Y. In vitro effects of artesunate on the survival of worm pairs and egg production of Schistosoma mansoni. J Helminthol 2009, 83, 7-11.

127. Thompson, D.P.; Klein, R.D.; Geary, T.G. Prospects for rational approaches to anthelmintic discovery. Parasitology 1996, 113, S217-S238.

128. Sangster, N.C.; Song, J.; Demeler, J. Resistance as a tool for discovering and understanding targets in parasite neuromusculature. Parasitology 2005, 131, S179-S190.

129. Marks, N.J.; Maule, A.G. Neuropeptides in helminths: Occurrence and distribution. Adv. Exp. Med. Biol. 2010, 692, 49-77.

130. Taman, A.; Ribeiro, P. Glutamate-mediated signaling in Schistosoma mansoni: A novel glutamate receptor is expressed in neurons and the female reproductive tract. Mol. Biochem. Parasitol. 2011, 176, 42-50.

131. Hillman, G.R.; Gibler, W.B.; Chu, S.H. Fluorescent probes of acetylcholine binding sites-indicators of drug action in Schistosoma mansoni. Biochem. Pharmacol. 1976, 25, 2529-2535.

132. Bizimana, N.; Tietjen, U.; Zessin, K.H.; Diallo, D.; Djibril, C.; Melzig, M.F.; Clausen, P.H. Evaluation of medicinal plants from Mali for their in vitro and in vivo trypanocidal activity. J. Ethnopharmacol. 2006, 103, 350-356.

133. Freiburghaus, F.; Kaminsky, R.; Nkunya, M.H.; Brun, R. Evaluation of African medicinal plants for their in vitro trypanocidal activity. J. Ethnopharmacol. 1996, 55, 1-11.

134. Youan, B.B.; Coulibaly, S.; Miezan, T.B.; Doua, F.; Bamba, M. In vivo evaluation of sixteen plant extracts on mice inoculated with Trypanosoma brucei gambiense. Bull. World Health Organ. 1997, 75, 343-348.

135. Dua, V.K.; Verma, G.; Agarwal, D.D.; Kaiser, M.; Brun, R. Antiprotozoal activities of traditional medicinal plants from the Garhwal region of North West Himalaya, India. J. Ethnopharmacol. 2011, 136, 123-128.

136. Mann, A.; Ifarajimi, O.R.; Adewoye, A.T.; Ukam, C.; Udeme, E.E.; Okorie, II; Sakpe, M.S.; Ibrahim, D.R.; Yahaya, Y.A.; Kabir, A.Y.; et al. In vivo antitrypanosomal effects of some ethnomedicinal plants from Nupeland of north central Nigeria. Afr. J. Tradit. Complement. Altern. Med. 2011, 8, 15-21. 
137. Buckner, F.S.N.N. Advances in Chagas disease drug development: 2009-2010. Curr. Opin. Infect. Dis. 2010, 23, 609-616.

138. Andrade e Silva, M.L.; Cicarelli, R.M.; Pauletti, P.M.; Luz, P.P.; Rezende, K.C.; Januario, A.H.; da Silva, R.; Pereira, A.C.; Bastos, J.K.; de Albuquerque, S.; et al. Trypanosoma cruzi: Evaluation of (-)-cubebin derivatives activity in the messenger RNAs processing. Parasitol. Res. 2011, 109, 445-451.

139. Parmar, V.S.J.; Gupta, S.; Talwar, S.; Rajwanshi, V.K.K.; Azim, A.; Malhotra, S.K.; Jain, R.; Sharma, N.K.; Tyagi, O.D.L.; Errington, W.; et al. Polyphenols and alkaloids from Piper species. Phytochemistry 1998, 49, 1069-1078.

140. Baldoqui, D.C.; Kato, M.J.; Cavalheiro, A.J.; Bolzani V.S.; Young, M.C.; Furlan, M.A. chromene and prenylated benzoic acid from Piper aduncum. Phytochemistry 1999, 51, 899-902.

141. Kato, M.J.; Furlan, M. Chemistry and evolution of the Piperaceae. Pure Appl. Chem. 2007, 79, 529-538.

142. Nour, A.M.; Khalid, S.A.; Kaiser, M.; Brun, R.; Abdallah, W.E.; Schmidt, T.J. The antiprotozoal activity of sixteen asteraceae species native to Sudan and bioactivity-guided isolation of xanthanolides from Xanthium brasilicum. Planta Med. 2009, 75, 1363-1368.

143. Batista, J.M., Jr.; Lopes, A.A.; Ambrosio, D.L.; Regasini, L.O.; Kato, M.J.; Bolzani V.S.; Cicarelli, R.M.; Furlan, M. Natural chromenes and chromene derivatives as potential anti-trypanosomal agents. Biol. Pharm. Bull. 2008, 31, 538-540.

144. Flores, N.; Jimenez, I.A.; Gimenez, A.; Ruiz, G.; Gutierrez, D.; Bourdy, G.; Bazzocchi, I.L. Antiparasitic activity of prenylated benzoic acid derivatives from Piper species. Phytochemistry 2009, 70, 621-627.

145. Flores, N.; Jimenez, I.A.; Gimenez, A.; Ruiz, G.; Gutierrez, D.; Bourdy, G.; Bazzocchi, I.L. Benzoic acid derivatives from Piper species and their antiparasitic activity. J. Nat. Prod. 2008, $71,1538-1543$.

146. Torres-Santos, E.C.; Moreira, D.L.; Kaplan, M.A.; Meirelles, M.N.; Rossi-Bergmann, B. Selective effect of 2',6'-dihydroxy-4'-methoxychalcone isolated from Piper aduncum on Leishmania amazonensis. Antimicrob Agents Chemother 1999, 43, 1234-1241.

147. Hermoso, A.; Jimenez, I.A.; Mamani, Z.A.; Bazzocchi, I.L.; Pinero, J.E.; Ravelo, A.G.; Valladares, B. Antileishmanial activities of dihydrochalcones from Piper elongatum and synthetic related compounds. Structural requirements for activity. Bioorg. Med. Chem. 2003, 11, 3975-3980.

148. Bodiwala, H.S.S.G.; Singh, R.; Dey, C.S.; Sharma, S.S.; Bhutani, K.K.; Singh, I.P. Antileishmanial amides and lignans from Piper cubeba and Piper retrofractum. J. Nat. Med. 2007, 61, 418-421.

149. Luize, P.S.; Ueda-Nakamura, T.; Dias Filho, B.P.; Cortez, D.A.; Nakamura, C.V. Activity of neolignans isolated from Piper regnellii (MIQ.) C.DC. var. pallescens against Trypanosoma cruzi. Biol. Pharm. Bull. 2006, 29, 2126-2130.

150. Martins, R.C.; Lago, J.H.; Albuquerque, S.; Kato, M.J. Trypanocidal tetrahydrofuran lignans from inflorescences of Piper solmsianum. Phytochemistry 2003, 64, 667-670. 
151. Ribeiro, T.S.; Freire-de-Lima, L.; Previato, J.O.; Mendonca-Previato, L.; Heise, N.; de Lima, M.E. Toxic effects of natural piperine and its derivatives on epimastigotes and amastigotes of Trypanosoma cruzi. Bioorg. Med. Chem. Lett. 2004, 14, 3555-3558.

152. Cotinguiba, F.R.; Bolzani, V.S.; Debonsi, H.M.; Passerini, G.D.; Cicarelli, R.M.B.; Kato, M.J.; Furlan, M. Piperamides and their derivatives as potential anti-trypanosomal agents. Med. Chem. Res. 2009, 18, 703-711.

153. Lopes, A.A.; Lopez, S.N.; Regasini, L.O.; Junior, J.M.; Ambrosio, D.L.; Kato, M.J.; da Silva Bolzani, V.; Cicarelli, R.M.; Furlan, M. In vitro activity of compounds isolated from Piper crassinervium against Trypanosoma cruzi. Nat. Prod. Res. 2008, 22, 1040-1046.

154. Ganfon, H.; Bero, J.; Tchinda, A.T.; Gbaguidi, F.; Gbenou, J.; Moudachirou, M.; Frederich, M.; Quetin-Leclercq, J. Antiparasitic activities of two sesquiterpenic lactones isolated from Acanthospermum hispidum D.C. J. Ethnopharmacol. 2012, 141, 411-417.

155. Nibret, E.; Ashour, M.L.; Rubanza, C.D.; Wink, M. Screening of some Tanzanian medicinal plants for their trypanocidal and cytotoxic activities. Phytother. Res. 2010, 24, 945-947.

156. Oliveira, M.F.; d'Avila, J.C.; Tempone, A.J.; Soares, J.B.; Rumjanek, F.D.; Ferreira-Pereira, A.; Ferreira, S.T.; Oliveira, P.L. Inhibition of heme aggregation by chloroquine reduces Schistosoma mansoni infection. J. Infect. Dis. 2004, 190, 843-852.

157. Jones, A.K.; Bentley, G.N.; Oliveros Parra, W.G.; Agnew, A. Molecular characterization of an acetylcholinesterase implicated in the regulation of glucose scavenging by the parasite Schistosoma. FASEB J 2002, 16, 441-443.

158. Abdulla, M.H.; Ruelas, D.S.; Wolff, B.; Snedecor, J.; Lim, K.C.; Xu, F.; Renslo, A.R.; Williams, J.; McKerrow, J.H.; Caffrey, C.R. Drug discovery for schistosomiasis: Hit and lead compounds identified in a library of known drugs by medium-throughput phenotypic screening. PLoS Negl. Trop. Dis. 2009, 3, e478.

159. Quezada, L.A.; McKerrow, J.H. Schistosome serine protease inhibitors: Parasite defense or homeostasis? An. Acad. Bras. Cienc. 2011, 83, 663-672.

160. Mendonca-Silva, D.L.; Pessoa, R.F.; Noel, F. Evidence for the presence of glutamatergic receptors in adult Schistosoma mansoni. Biochem. Pharmacol. 2002, 64, 1337-1344.

(C) 2013 by the authors; licensee MDPI, Basel, Switzerland. This article is an open access article distributed under the terms and conditions of the Creative Commons Attribution license (http://creativecommons.org/licenses/by/3.0/). 